\title{
The Economic Determinants of Conditional Conservatism $=$
}

\author{
Juan Manuel García Lara, Beatriz García Osma \\ and Fernando Penalva*
}

\begin{abstract}
We study the economic determinants of conditional conservatism. Consistent with prior literature, we find that contracting induces only conditional conservatism and litigation induces both conditional and unconditional conservatism. We extend prior evidence by Qiang (2007) by showing that taxation and regulation induce not only unconditional conservatism, but conditional conservatism as well. We show that in certain scenarios taxation and regulation create incentives to shift income from periods with high taxation pressure and high public scrutiny to periods with lower taxation pressure and lower public scrutiny. These income shifting strategies are implemented by recognising current economic losses that, given managerial incentives to report aggressively, would not have been recognized otherwise, or by delaying the recognition of current economic gains that would have been recognized had circumstances been different.
\end{abstract}

Keywords: conservatism, contracting, taxation, political costs, litigation risk

\section{INTRODUCTION}

There is scarce empirical evidence and mixed views on which are the economic determinants of conservatism in accounting and what types of conservatism they trigger. Watts (2003) identifies four main triggering factors for conservatism: contracting, litigation, taxation and regulation. Ball (2001), Ball and Shivakumar (2005) and Basu (2005) similarly point at these factors as being the main determinants of conservatism in accounting. However, in the spirit of Beaver and Ryan (2005), these authors theorize

\footnotetext{
* The authors are respectively from Universidad Carlos III de Madrid, Universidad Autónoma de Madrid and IESE Business School, University of Navarra. They gratefully acknowledge helpful comments and suggestions from Peter F. Pope (editor) and an anonymous referee. They are also grateful to Sophia Hamm, conference participants at the 2008 JBFA capital markets conference, the 2008 AAA annual meeting, the 2007 and 2008 EAA annual meetings and the 2007 AECA Congress, and seminar participants at Tilburg University, Instituto de Empresa Business School, University Federico II of Naples and ISCTE Business School. The authors would also like to thank John Graham, who kindly provided estimates for the marginal tax rate. They acknowledge financial assistance from IESE Research Division, the Spanish Ministry of Science and Innovation (ECO2008-06238-C02-01/ECON and SEJ2007-67582-C02-02/ECON), and the European Commission INTACCT Research Training Network (MRTN-CT-2006-035850).
}

Address for correspondence: Fernando Penalva, IESE Business School, University of Navarra, Av. Pearson, 21, 08034 Barcelona, Spain.

e-mail: penalva@iese.edu 
that each of these determinants likely creates incentives for only one out of two separate types of conservatism: either (1) for ex-ante, news-unrelated or unconditional conservatism, or (2) for ex-post, news-related or conditional conservatism.

There is some consensus in the existing literature that contracting and litigation induce conditional conservatism, defined by Basu (1997) as the existence of stronger verification requirements for the recognition of economic gains than for the recognition of economic losses, generating earnings that reflect bad news in a timelier fashion than good news. Regarding taxation and regulation, Ball (2001), Ball and Shivakumar (2005) and Basu (2005) argue that they likely induce only conservatism in its unconditional form, which implies that 'aspects of the accounting process determined at the inception of assets or liabilities yield expected unrecorded goodwill' (Beaver and Ryan, 2005, p. 269). Recent empirical research on the determinants of conservatism by Qiang (2007) finds evidence consistent with contracting triggering conditional conservatism, litigation triggering both conditional and unconditional conservatism, and taxation and regulation triggering only unconditional conservatism.

In this paper, we revisit the issue of whether conditional conservatism varies with contracting, litigation, taxation and regulation. In particular, we re-examine whether regulation and taxation can also induce conditional conservatism. While we agree that unconditional conservatism, as a long-run accounting policy, helps managers to minimize tax payments and that standard setters and other regulators likely have a preference for a stronger form of conservatism such as the unconditional form, to avoid blame from constituents, we argue that managers also face tax-related and political costrelated incentives to report conditionally conservative numbers.

Regarding taxation, the decrease in the net present value of tax payments that Watts (2003) puts forward as an explanation to why managers implement conservative accounting practices, can be achieved: (1) by delaying tax payments through unconditional conservatism, i.e., via the persistent understatement of net assets, and (2) by shifting income from periods with high marginal tax rates to periods with low marginal tax rates. Unconditional conservatism is not an efficient tool to shift income across periods as it lacks flexibility, and current understatements translate into net income overstatements in future periods when marginal tax rates may be higher for the specific firm, or for all firms, if statutory tax rates increase. Managers choosing to shift income across periods will resort to either recognizing current economic losses on a very timely basis, or to delaying the recognition of current economic gains to future periods with lower marginal tax rates (or to both strategies), to reduce current income. Thus, high marginal tax rates will decrease managers' incentives for aggressive earnings management practices and will contribute to increased conditional conservatism.

With respect to regulation, standard setters and other regulators enforce a certain degree of unconditional conservatism by imposing accounting standards that are based on historical cost, that do not allow the capitalization of $\mathrm{R} \& \mathrm{D}$ costs, etc. However, the unconditional conservatism resulting from these regulatory demands does not shield firms and managers from political costs and regulatory scrutiny. Managers still have incentives to use the remaining flexibility within accounting standards to reduce political costs, by shifting income from periods with high political visibility and high expected political costs to periods with low political visibility and low expected political costs. As with taxation, to lower political visibility, managers will reduce earnings through the timely recognition of current economic losses, or through lower aggressiveness in recognizing current economic gains. 
Qiang's (2007) result of no association between conditional conservatism and taxation or regulation is attributable to the use of empirical proxies to measure tax pressures and regulation costs that fail to capture the scenarios described above (situations where the firm faces a high current marginal tax rate or high current political visibility) where managers have incentives to shift income across periods, and where conditional conservatism can be an efficient tool to achieve this objective.

Applying the model proposed by Basu (1997) to a large sample of US firms for the period 1964 to 2005 , we conduct a simple test to analyse the effect of each of these four conditional conservatism triggering factors on an individual basis. First, we show that conditional conservatism is positively associated to several proxies for contracting incentives to use conservative numbers. Second, we find that litigation risk, as measured by a firm-specific proxy designed to capture time-series variation in litigation exposure, induces conditional conservatism and that, consistent with Qiang, firm-specific proxies of litigation risk are associated with unconditional conservatism. Third, our results are consistent with taxation pressures that create incentives to shift income across periods (to minimize tax payments) inducing conditional conservatism, while booktax conformity proxies capturing tax pressures that do not particularly change over time are associated with unconditional conservatism. Finally, regulation pressures as measured by time-series economy-wide proxies induce conditional conservatism; while firm-specific regulation pressures reflecting high market-shares, which tend to be stable over time, induce unconditional conservatism.

As an additional test, we create 247 portfolios of firm-year observations, according to the aggregate exposure to the four economic determinants of conditional conservatism and to the presence of unconditional conservatism. We expect that firms in the portfolio with the higher probability of conservative accounting choices - as denoted by high exposure to all four factors - will present more conditionally conservative earnings. Our results are consistent with this expectation: firms with higher joint exposure to these factors exhibit a higher level of conditional conservatism. Finally, we also show that firms where unconditional conservatism plays a substantive role show less pronounced conditional conservatism. This is consistent with the argument in Beaver and Ryan (2005) that unconditional conservatism pre-empts conditional conservatism.

Our study expands previous empirical research by Qiang (2007) by showing that taxation and regulation also induce conditional conservatism. Specifically, our results show that managers respond to increases in tax-related and political cost-related pressures by increasing conditional conservatism. In addition, we improve on Qiang's measures by constructing proxies for the economic determinants of conditional conservatism that combine time-series and cross-sectional variation. Her proxies are firm-specific averages over her sample period, and thus, cannot capture temporal variation. We also show that, in agreement with the arguments in Ball and Shivakumar (2005), contracting generates only a demand for conditional conservatism. Consistent with Qiang, we find that litigation risk induces both conditional and unconditional conservatism. Finally, we provide a very simple and intuitive joint-test of the factors that drive the demand for conditional conservatism.

The remainder of the paper is structured as follows: in Section 2 we explain the expected association between conditional conservatism and the four economic determinants: contracting, litigation, taxation and political costs. Section 3 describes the research design. Section 4 discusses the results and robustness checks. Finally, 
Section 5 summarizes the main findings of the paper and the implications of our results for subsequent research on conservatism.

\section{THE DETERMINANTS OF CONDITIONAL CONSERVATISM}

Prior research on conservatism points out four main explanations for the existence of voluntary conservative practices (Watts, 2003): (i) contracting, (ii) litigation risk, (iii) taxation, and (iv) political costs. Conservative accounting numbers are achieved, as shown by Beaver and Ryan (2005) through two channels. First, firms report conservative numbers unconditionally by recording assets at a value that is lower than their economic value, or not capitalising them at all. Examples are the nonrecognition of internally generated intangible assets, the use of historic cost accounting or the use of depreciation/amortization rates in excess of economic depreciation that creates unrecorded goodwill. Second, firms report conditionally conservative accounting numbers when they use different verifiability criteria to recognize economic gains and losses in the income statement (Basu, 1997). Conditional conservatism exists when economic losses are recognized in the income statement faster than economic gains.

In this section we describe how contracting, litigation, taxation and political costs contribute to the existence of conditional conservatism. ${ }^{1}$ We argue that contracting induces only conditional conservatism, while litigation, taxation and political costs induce both conditional and unconditional conservatism. Prior research by Ball (2001), Ball and Shivakumar (2005), Basu (2005) and Qiang (2007) argues that taxation and political costs are likely to induce conservatism only in its unconditional form. We show that, under certain circumstances, taxation pressures and political costs also generate incentives to report conditionally conservative earnings numbers.

\section{(i) Contracting Incentives}

Recent work by Holthausen and Watts (2001), Watts (2003), Guay and Verrecchia (2006) and Ball, Robin and Sadka (2008) concurs in pointing out debt contracting as the main economic determinant of conditionally conservative reporting. In general, the value of debt claims is more sensitive to decreases than to increases in firm value. Consequently, debt contracts treat gains and losses asymmetrically (Ball et al., 2008; and Beatty, Weber and $\mathrm{Yu}, 2008$ ). Because economic losses decrease the value of debt, lenders protect themselves against loss-making managers by introducing covenants into debt contracts that permit restricting major decisions that further decrease the value of the outstanding debt and that reduce the probability that the creditors will see their investment returned (such as excessive cash payouts in the form of dividends, new acquisitions or borrowings.)

Debt contracts are commonly written in terms of variables reported in the financial statements, such as interest coverage or financial leverage. Conservative accounting

1 We assume that most of the variation in conditional conservatism is caused by firms' choices in response to these drivers. Accounting standard-setters are likely to respond to these same economic forces by enacting the demanded accounting standards. In turn, firms respond by making choices within the accepted set of GAAP to achieve the desired level of conditional conservatism. We are grateful to an anonymous referee for this insight. 
facilitates the monitoring of these contracts, improving the efficiency of contracting ex-ante by providing lenders with information that permits writing the terms of the loan more efficiently, and ex-post by triggering debt-covenant violations faster (Ball and Shivakumar, 2005). Timely covenant violation thus becomes an efficient mechanism for lenders to exercise their contractual rights and restrict decisions by lossmaking managers that could further erode debt quality (Ball et al., 2008). In addition, conditionally conservative accounting limits the available opportunities for successful manipulation of the reported variables included in debt contracts to expropriate the lenders. Thus, it is predicted that debt holders will demand conditionally conservative earnings.

Supporting this prediction, recent work by Ball et al. (2008) finds a positive association between conditional conservatism and the size of international debt markets. Additionally, Ahmed et al. (2002) show that more conservative firms benefit from a lower cost of debt, consistent with debt-holders rewarding firms that use more conservative accounting by demanding a lower rate of return. Put together, this evidence is consistent with debt-holders demanding conservative accounting numbers. We are not aware of the existence of any previous study directly addressing firm-level variation in conditional conservatism due to debt contracting and the debt covenant provisions included in those contracts.

In addition to debt contracting, Basu (1997) and Ball (2001) emphasize managerial contracting as a source of demand for conditional conservatism. Compensation contracts based to some extent on accounting numbers create incentives for aggressive accounting (Healy, 1985). This, in turn, generates investors' demand for conditional conservatism to avoid expropriation. Investors will therefore require strong governance mechanisms that can enforce conservative accounting choices. Recent evidence in Beekes, Pope and Young (2004), Ahmed and Duellman (2007) and García Lara, García Osma and Penalva (2007 and 2009) confirms that stronger corporate governance is associated with increased conditional conservatism.

\section{(ii) Exposure to Litigation Risk}

Shareholder litigation is a significant source of conservatism, particularly, in recent years. The US is a highly litigious environment with a well-founded legal system, strong legal investor protection for creditors and shareholders (La Porta, Lopez-de-Silanes and Shleifer, 1998 and 1999), and low costs associated to naming public defendants (Stice, 1991; Ball, Kothari and Robin, 2000; and Khurana and Raman, 2004). Firm litigation risk arises when the different parties to the firm can sue (or can threaten to sue) managers, directors or auditors in an attempt to recover incurred losses by attributing them to defects in the financial statements, thereby assigning responsibility for the losses to accounting numbers not reflecting the true underlying economic performance of the firm.

Against this framework, conditional conservatism plays an important role in mitigating the negative effects of information asymmetries, reducing moral hazard, adverse selection and other agency problems, and thus, contributing to reduce litigation risk. The asymmetric recognition requirements for economic gains and losses are closely linked to asymmetries in the loss function of directors and auditors: overstating (understating) net assets or earnings is more (less) likely to generate litigation costs. Consistent with this view, extant research on auditor litigation shows that lawsuits against 
auditors are almost always related to situations where earnings or net assets have been overstated (Kellogg, 1984; and St. Pierre and Anderson, 1984) or where the firm reports significant income-increasing abnormal accruals (Heninger, 2001).

Therefore, litigation risk produces asymmetric payoffs, and the assessment of these loss functions depends on the general legal environment or legal regime (Seetharaman, Gul and Lynn, 2002), i.e., on the extent to which the legal system allows small investors to sue the corporation, managers, directors or auditors, with the expectation that the outcome of the litigation process will favour the more vulnerable party (the investor). This assessment of litigation risk varies depending on changes in the severity of the legal environment and determines managerial, auditor and director's effort to reduce expected liability loss payments.

Empirical research on the association between litigation risk and conditional conservatism has analysed (1) whether there are differences in conditional conservatism between countries with diverging levels of litigation risk exposure; (2) whether conditional conservatism has varied historically in the US as a response to period changes in the overall levels of firms' exposure to litigation risk; and (3) whether firm-level litigation induces both conditional and unconditional conservatism. In an international context, Ball et al. (2000) and Bushman and Piotroski (2006) show that in Anglo-Saxon common-law countries, where litigation risk is more pronounced, conditional conservatism measures are significantly larger than in countries where investors' expected chances of successfully defending their interests over the firm in court are low. In addition, Ball, Robin and Wu (2003) also show that conditional conservatism across several common-law countries varies with litigation risk. Regarding the evolution of conditional conservatism over time in the US, evidence in Basu (1997) and Holthausen and Watts (2001) demonstrates that conditional conservatism has increased (decreased) whenever there has been an increase (decrease) in litigation risk. Finally, Qiang (2007) shows that firm-level proxies for litigation risk are associated to larger measures of both conditional and unconditional conservatism, and Chung and Wynn (2008) demonstrate that managers can use conditional conservatism as insurance against litigation costs.

Based on the prior arguments and results, we expect that conditional conservatism will vary with firms' exposure to litigation risk. Even if unconditional conservatism increases as well with litigation risk, we expect that the increased use of unconditional conservatism does not completely exhaust managerial opportunities (and incentives) to increase conditional conservatism to further protect themselves from litigation exposure (Chung and Wynn, 2008). As managers, directors and auditors become increasingly concerned about potential lawsuits, they are expected to increase their demand for conditional conservative accounting choices (regardless of the initial stock of unconditional conservatism), increasing the timeliness of earnings to economic losses and delaying the recognition of difficult-to-verify economic gains. Thus, the higher the litigation risk, the higher the expected conditional conservatism.

\section{(iii) Tax Sheltering to Minimize Tax Payments}

Tax considerations affect financial accounting choices (Shackelford and Shevlin, 2001). Even though financial accounting and tax accounting often differ in a number of ways (for example, different revenue and expense recognition criteria), tax planning usually involves managerial use of accounting discretion to minimise the present value of tax 
payments. Both unconditional and conditional conservatism are used by managers as vehicles to reduce the present value of taxes and, thus, to increase firm value. Unconditionally conservative accounting anticipates the recognition of economic losses, which delays tax payments, irrespective of the current marginal tax rate faced by the firm. Therefore, the adoption of unconditionally conservative accounting policies lacks flexibility, as it cannot be used to reduce the value of tax payments by allocating income to periods with lower marginal tax rates. Managers cannot respond in a timely manner to changes in their marginal tax rates using unconditionally conservative measures. Conditional conservatism is then used to shift current income across periods: from periods with high expected tax rates to periods with lower expected tax rates. This shifting of income reduces not only the net present value of tax payments, but the overall amount to be paid. Therefore, in a scenario where firms face greater tax pressures, it is less (more) costly to recognise current economic losses (gains) and thus, managerial incentives to report aggressively are reduced.

Tax avoidance (also referred to as tax-sheltering) is a widespread practice in US corporations (Desai and Dharmapala, 2006), particularly in large multinational companies (Rego, 2003). Managers shift income across periods to minimize tax payments transitorily to circumvent changes in tax regulation - as happened with the Tax Reform Act of 1986, that created incentives to shift income temporarily (Scholes, Wilson and Wolfson, 1992; and Guenther, 1994) — but also as a long-run strategy that managers maintain for long periods of time. In fact, recent evidence suggests that a significant number of firms succeed at keeping their effective tax rates low for periods of up to 10 consecutive years (Dyreng, Hanlon and Maydew, 2008), and that managers make use of the discretion inherent to accruals calculation to manage earnings downwards for tax purposes (Badertscher, Phillips, Pincus and Rego, 2006). Unconditional conservatism, implemented mainly through the direct expensing of certain costs (like R\&D costs) and accelerated amortisation/depreciation of assets, is not flexible enough to successfully implement these income shifting strategies. It is more likely that managers will opt for recognizing economic losses that, without the taxdriven income shifting incentives, they would have disregarded. Examples of accruals that generate both book and tax deductions and give rise to conditional conservatism are increases in cost of goods sold (through the anticipation of ending inventory writeoffs), or increases in bad debt expense (through the anticipation of receivables writeoffs). This is possible because determining when inventory or receivables become worthless is a judgment call. The anticipation of write-offs usually takes place in the fourth quarter so that the increase in cost of goods sold or in bad debt expense occurs in the same fiscal year as the recognition of the additional write-offs. This element of judgment provides firms with valuable discretion in the timing of both the book expense and the tax deduction (IRS Publications 535 and 538). Shackelford, Slemrod, and Salle (2007, pp. 31-32) state that:

by timing the write-offs of receivables, the company may be able to maximize the tax savings from both operational losses and write-offs; they also gain discretion in the recognition of book income. ${ }^{2}$

2 See Northcut and Vines (1998) for additional examples of accruals that are high in book-tax conformity and a summary of prior research on how managers reduce book income to reduce tax costs. 
In addition, from a real operations management perspective, Badertscher et al. (2006) argue that managers also change firms' operating activities to reduce both book income and taxable income and thus generate current tax benefits. Tax pressures are also expected to reduce the incentives for real earnings manipulation. Managers can reduce earnings in a book-tax conforming manner by not anticipating revenue recognition and not delaying real operating expenses, thereby reducing the present value of tax payments (for example, by accelerating their contribution to pension plans). Thus, we expect that the incentives to minimize tax payments through conditional conservatism will be higher as the firm tax pressure increases.

\section{(iv) Firm Political Costs}

Highly profitable firms draw attention from the media, employees, consumers, labour unions, and other pressure groups. These groups can translate this attention to regulators, lobbying for the nationalization, expropriation, break-up or regulation of a specific industry or corporation. Regulators, in turn, may respond with new taxes, antitrust investigations, reductions in government subsidies or changes in price regulation. One of the three classic hypotheses of the influential positive accounting theory developed by Watts and Zimmerman (1978 and 1986) is that corporations and industries counter these potential government intrusions by choosing accounting methods that minimize current earnings to lower their public visibility and thus minimise political scrutiny (Cahan, 1992; and Key, 1997).

The existence of political costs is particularly true for regulated industries, where high reported profits are easily associated to monopoly rents. For industries where prices are regulated, high profitability is likely answered by regulators by imposing caps on prices. It is expected that in response to these pressures, managers attempt to minimize the likelihood of adverse political action by reducing their earnings. Thus, being exposed to high political costs (for example, pertaining to a regulated industry) generates incentives to engage in more pronounced conditional and unconditional conservative accounting choices.

Accounting standards will impose a certain degree of unconditional conservatism (for example, demanding direct expensing of R\&D costs). Given this compulsory level of unconditional conservatism, managers interested in achieving additional decreases in earnings to lower their visibility will recognise current economic losses that, given managers incentives to report aggressively, they would not have recognized otherwise, or they will delay the recognition of current economic gains that they would have recognized had circumstances been different. Empirical results in Jones (1991), Cahan (1992), Key (1997), Han and Wang (1998) and Navissi (1999), among others, show that managers of firms under political scrutiny choose income-decreasing strategies. This is consistent with managers shifting income from periods of high political visibility to periods with reduced political visibility. These income-decreasing strategies would enhance (reduce) the association between earnings and returns in bad (good) news periods, contributing to increased conditional conservatism as measured by Basu (1997).

Qiang (2007) argues that regulators have a preference for unconditional versus conditional conservatism, because unconditional conservatism leads to smoother earnings and reduces the occurrence of large negative shocks, and that they (regulators) can drive managers into unconditionally conservative practices by imposing regulation costs on firms (restatements and SEC investigations). While we agree that 
accounting standard setters will induce unconditional conservatism, we also expect that regulators' monitoring will provide managers with incentives for voluntarily fostering the recognition of bad news. In fact, we expect that the asymmetric loss function of regulators will create a demand for conditional conservatism. For example, in periods of economic downturn, regulators face significant public scrutiny and demands, whilst they do not attract similar attention in periods of economy-wide growth. In this context of increased public scrutiny, regulator pressures will likely translate into managers shifting income from periods of increased public scrutiny, to periods with lower public scrutiny. To lower their visibility managers will recognize current economic losses that, given their incentives to report aggressively, they would not have recognized otherwise, or they will delay the recognition of current gains that they would have recognized under lower political scrutiny. Besides, a large stock of unconditional conservatism is bound to reduce the asset base and lead to higher profitability as measured, for example, by the return-on-assets (ROA). Therefore, the incentives to report low profitability measures might trigger a trade-off between unconditional and conditional conservatism. Consistent with the view that regulation induces conditional conservatism, research by Sivakumar and Waymire (2003) demonstrates that the introduction of tighter accounting standards together with rate regulation increased the conditionally conservative behaviour of early 20 th century railroad firms.

\section{(v) Unconditional Conservatism}

While conditional conservatism refers to how quickly the accounting system captures increases or decreases in wealth (assuming that conditional conservatism exists when decreases in wealth are captured faster than increases in wealth), unconditional conservatism involves the persistent understatement of net assets (through quicker amortization/depreciation or non-recognition). Unconditional conservatism is therefore independent of news. This is the case with the expensing (as opposed to capitalization and subsequent amortization) of R\&D costs.

As argued by Giner and Rees (2001), Basu (2001), Pope and Walker (2003) and Beaver and Ryan (2005), unconditional conservatism pre-empts conditional conservatism. A firm not capitalizing $R \& D$ when the costs are incurred is more unconditionally conservative. A firm capitalizing R\&D expenditures will subsequently amortize them, incurring more pronounced conditional conservatism. However, the non-capitalizing firm, by being more unconditionally conservative, will appear to be less conditionally conservative in the future if compared to the capitalizing firm. This is so because possible bad outcomes of the research project will not affect the financial statements, as unrecognized assets cannot be written-off. Following Beaver and Ryan (2005), we expect that firms with high levels of unconditional conservatism will show less pronounced measures of conditional conservatism. Measuring unconditional conservatism is not a simple task. Recent research uses the market-to-book ratio (also a proxy for growth and risk), the C-Score proposed by Penman and Zhang (2002), the intercept of the Basu (1997) regression, or the bias component developed by Beaver and Ryan (2000) as measures of unconditional conservatism.

\section{RESEARCH DESIGN}

This section provides a description of the procedures we follow to test the effect of the four identified economic determinants of conditional conservatism: (i) contracting; 
(ii) litigation risk; (iii) taxation; and (iv) political costs. Conditional conservatism is estimated from a Basu (1997) earnings-returns regression. We use several proxies for contracting, litigation, taxation and political costs. We expect all contracting proxies to be positively associated with conditional conservatism. Regarding litigation, taxation and regulation, we expect firm-level proxies with little time series variation to capture incentives for unconditional conservatism, while we expect proxies that vary over time to proxy for income-shifting incentives that induce conditional conservatism in accounting.

\section{(i) Empirical Proxies of Conditional Conservatism}

Our proxy of conditional conservatism is based on Basu's (1997) measure. Under conservative accounting, earnings capture bad news faster than good news because of the asymmetric standards of verification of losses and gains. Basu uses stock returns to proxy for good and bad news. Stock prices incorporate all the information arriving to the market from multiple sources, including reported earnings, in a timely fashion. Therefore, stock price changes are a measure of news arrival during the period. Because earnings are timelier in recognizing bad news than good news, Basu expects to find a higher association of earnings with negative returns (the bad news proxy) than with positive returns (the good news proxy). We use Basu's regression as follows:

$$
X_{t}=\beta_{0}+\beta_{1} D_{t}+\beta_{2} R_{t}+\beta_{3} D_{t} R_{t}+\mu_{t}
$$

where $X_{t}$ is net income, deflated by the firm's market value of equity at the beginning of the period. ${ }^{3} R_{t}$ is the annual stock rate of return of the firm, measured compounding twelve monthly CRSP stock returns ending three months after the last day of fiscal year $t$. $D_{t}$ is a dummy variable that equals 1 in the case of bad news (negative or zero rate of return) and 0 in the case of good news (positive stock rate of return). The coefficient $\beta_{3}$ measures the level of asymmetric timeliness —of conditional conservatism- and it is expected to be positive and significant.

Basu's approach has been used by a large number of studies analysing how conditional conservatism varies with certain firm-specific characteristics and with the evolution of legal liability exposure over time, yielding economically sensible results, that is, finding more pronounced earnings asymmetric timeliness for samples where this was expected. ${ }^{4}$ Figure 1 presents the time-evolution of the annual $\beta_{3}$ coefficients obtained from the Basu market-based measure of conditional conservatism. Previous scholarly work in this area (Basu, 1997; and Holthausen and Watts, 2001) identifies two periods of high auditor litigation risk in which higher conditional conservatism is expected: 1967 to 1975 and 1983 to 1995 . The descriptive evidence in Figure 1 indicates that conditional conservatism as per Basu increases in these periods, as expected. Also, Figure 1 suggests that conditional conservatism increased in the recent

3 We replicate our main tests using earnings before extraordinary items and discontinued operations. Results and inferences remain unchanged.

4 See, for example, Pope and Walker (1999), Ball et al. (2000), Givoly and Hayn (2000), Giner and Rees (2001), Basu, Hwang and Jan (2001), Ball et al. (2003), Ryan and Zarowin (2003), Raonic, McLeay and Asimakopoulos (2004), Beekes et al. (2004), García Lara, García Osma and Mora (2005), Huijgen and Lubberink (2005), Gassen, Fulbier and Sellhorn (2006), Bushman and Piotroski (2006), Roychowdhury and Watts (2007), Ball et al. (2008), LaFond and Watts (2008) and García Lara et al. (2008) among others. 
Figure 1

Time-Evolution of the Basu (1997) Measure of Conditional Conservatism

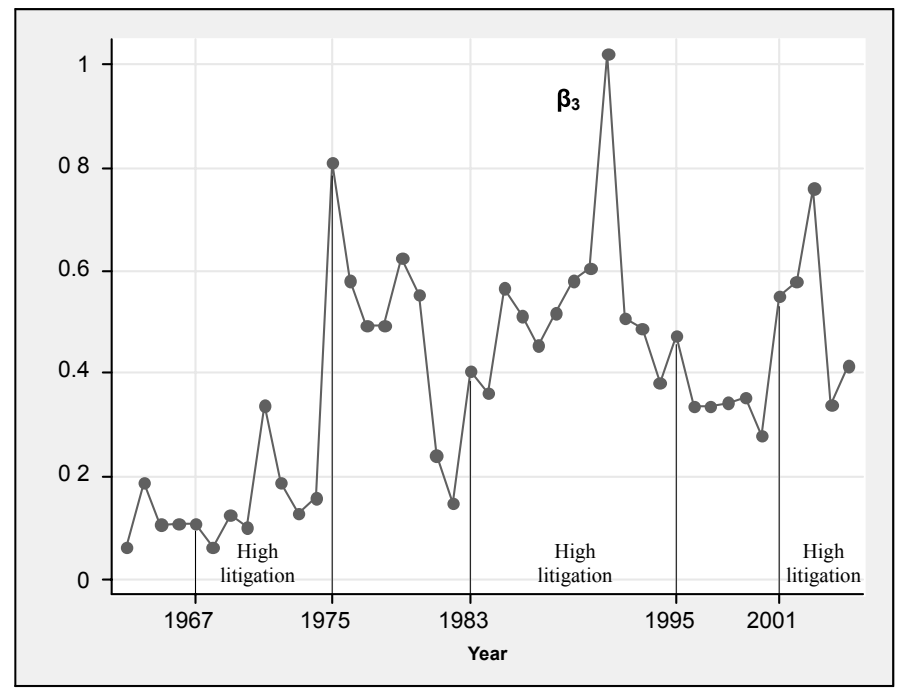

Notes:

Graph of the incremental bad news coefficient $\beta_{3}$ obtained from annual regressions of the Basu model:

$$
X_{t}=\beta_{0}+\beta_{1} D_{t}+\beta_{2} R_{t}+\beta_{3} D_{t} R_{t}+\mu_{t}
$$

where $X$ is net income, deflated by market value of equity at the beginning of the period. $R$ is the stock rate of return of the firm, measured compounding twelve monthly CRSP stock returns ending three months after fiscal year end. $D$ is a dummy variable that equals 1 in the case of bad news (negative or zero stock rate of return) and 0 in the case of good news (positive stock rate of return). The vertical lines mark high auditor litigation periods, defined as 1967 to 1975,1983 to 1995, and 2001 to 2005 . The annual regressions are based on a sample of 179,985 firm-year observations for the period 1963-2005, corresponding to 18,604 different firms.

Sarbanes-Oxley (SOX) era (after 2001), which corroborates the hypothesis in Basu (1997) and indicates that the Basu measure correctly picks up changes in conditional conservatism despite recent published criticism. ${ }^{5}$

\section{(ii) Analysis of the Impact of Conditional Conservatism Triggering Factors}

To study the impact of contracts, litigation risk, taxation, and political costs on the empirical measures of conditional conservatism, we incorporate proxies for each of the four determinants of conditional conservatism (as well as proxies for unconditional

5 Basu's model has been subject to criticism along two main fronts: (1) it cannot be used in time-series analysis to provide firm-specific measures of conservatism (Givoly and Hayn, 2000; Callen, Hope and Segal, 2008; and Givoly, Hayn and Natarajan, 2007); and (2) it might partly induce the asymmetry it aims to test (Dietrich, Muller and Riedl, 2007). However, Ryan (2006) and Ball and Kothari (2007) show that Dietrich et al.'s criticisms are unwarranted, and evidence in García Lara et al. (2009) is consistent with the biases being small and unlikely to alter inferences. 
conservatism) into the Basu conditional conservatism model as follows:

$$
\begin{aligned}
X_{t}= & \beta_{0}+\beta_{1} D_{t}+\beta_{01} \mathrm{DET}_{t}+\beta_{11} D_{t} \mathrm{DET}_{t}+\beta_{2} R_{t}+\beta_{21} R_{t} \mathrm{DET}_{t} \\
& +\beta_{3} D_{t} R_{t}+\beta_{31} D_{t} R_{t} \mathrm{DET}_{t}+\mu_{t} .
\end{aligned}
$$

Where DET is alternatively each of the four economic determinants of conditional conservatism identified in Section 2 above, and all other variables are defined as before. Model (2) is run separately for each of the determinants. Our empirical proxies for each of the four determinants capture both cross-sectional and time-series variation in each factor. As we explain in more detail below, several of the determinants likely induce both conditional and unconditional conservatism in accounting, and thus, it is important to define empirical proxies that correctly capture the incentives for conditional conservatism. For example, given the evidence in Qiang (2007), we expect to find a negative association between conditional conservatism and firm-specific litigation risk. Firm-specific litigation risk exhibits little variation over time, and thus it likely induces unconditional conservatism. However, economy-wide litigation risk varies substantially over time and induces changes in conditional conservatism (Basu, 1997; and Holthausen and Watts, 2001). These effects will be captured by the $\beta_{31}$ coefficient in model (2). In this model, positive (negative) values of $\beta_{31}$ signify that higher values of the identified determinant are associated to higher (lower) levels of conditional conservatism. We explain below how different pressures derived from contracting, litigation, taxation and regulation, as captured by different proxies, lead to incentives for engaging in conditional or unconditional conservative accounting choices.

\section{(a) Contracting Incentives for Conditional Conservatism}

We use leverage (LEV) as a proxy for the pressures received from debt-holders to report conditionally conservative earnings. To measure LEV, we first estimate firms' leverage as the ratio of total interest-bearing debt to total assets, both measured at the beginning of the fiscal year. This proxy of firm's leverage is then interacted with the Moody's seasoned Baa corporate bond annual yield (in percentage). Firms with higher leverage are expected to face incentives for conditional conservatism, particularly, in years when the corporate bond yield rate is greater. As a sensitivity check, we repeat our tests using two additional measures of leverage: (a) raw leverage (not interacted with the annual bond yield); and (b) industry-adjusted leverage, calculated adjusting firm leverage by subtracting the two-digit SIC leverage industry mean. Our results are not sensitive to these alternative specifications.

Additionally, in our sensitivity tests, we use measures of the strength of firm governance structures as proxies for the expected costs from compensation or equity contracting. Prior research shows that better governed firms present more conditionally conservative numbers. We use the governance measure (GOV) proposed by Davila and Penalva (2006), which includes both internal and external corporate governance provisions. Higher levels of GOV indicate better governance (low antitakeover protection and low CEO involvement in board decisions). Corporate governance quality (GOV) captures investors demand for tighter monitoring in the presence of accounting- or equity- based contracting that may generate incentives for 
aggressive accounting choices. Better governance is expected to induce conditional conservatism.

\section{(b) Litigation Risk Incentives for Conditional and Unconditional}

\section{Conservatism}

We use two measures of litigation risk that capture different incentives for implementing conditional versus unconditional conservative practices. Our first proxy of litigation risk (LITA) is designed to capture auditor litigation incentives for conditional conservative reporting. LITA is an indicator variable that equals 1 if the company's auditor is a big auditing firm (Compustat item \#149 between 1 and 8) and if the fiscal year is in a high auditor litigation period; and 0 otherwise. Following Basu (1997) and Holthausen and Watts (2001), we take the three periods comprising 1967 to 1975, 1983 to 1995, and 2001 to 2005 as of high auditor litigation risk. The latter period accounts for the increase in litigation that followed the spate of accounting scandals (Enron, WorldCom, Adelphia, etc.). Consistent with prior evidence by Basu (1997) and Holthausen and Watts (2001), we expect LITA to induce conditional conservatism.

As our second proxy for litigation risk, designed to capture litigation-related incentives to implement unconditionally conservative numbers, we measure the level of firm-specific litigation risk using the proxy proposed by Johnson, Kasznik and Nelson (2001). We refer to this variable as Firm litigation risk, defined as the first factor of a principal component analysis of five variables: log of assets, beta, stock returns, returns skewness and stock turnover. Firm litigation risk captures the firm's market volatility. Higher values of Firm litigation risk have been shown to be associated with greater likelihood of being sued. Finally, we construct LITF as an indicator variable that takes the value of 1 if Firm litigation risk is in the top quartile; and 0 otherwise. LITF is expected to induce mainly unconditional conservatism.

\section{(c) Taxation Driven Incentives for Conditional and Unconditional Conservatism}

To analyse the effect of taxation over conservatism we create two proxies: a proxy of firmyear level tax pressures, which are expected to induce conditional conservatism, and a proxy of book-tax conformity that is expected to capture incentives for unconditional conservatism.

With respect to tax-related incentives for conditional conservatism, we posit that managerial incentives to delay tax payments are directly associated to current-period tax pressures faced by the firm. We measure firm-specific tax pressures using a proxy for the marginal tax rate (TAX), that equals the highest statutory corporate income tax rate if the firm has a high marginal tax rate; and 0 otherwise. We follow Plesko (2003) and assume that a firm enjoys a low marginal tax rate if it has unused net operating loss carryforwards and zero or negative pre-tax income. Otherwise, firms are assumed to have a high marginal tax rate. Plesko shows that this proxy is almost as good as the real marginal tax rate computed from data in the firm's tax return. This simple approximation also compares favourably with the simulated marginal tax rates derived in Graham (1996). However, marginal tax rate is at least partially a function of net income, the dependent variable in model (2), which could introduce 
an econometric problem (Hausman and Wise, 1977). To correct this problem, we first run a regression of TAX on net income, and define our tax proxy (TAX $c$ ) as the residuals from this regression. This ensures that TAX $c$ is orthogonal to the dependent variable in regression (2). ${ }^{6}$

Since the Plesko (2003) proxy was only validated on a few recent years' actual tax returns, its accuracy is not guaranteed in prior years. As a sensitivity test we use an alternative proxy for the marginal tax rate developed by Graham (1996) and Graham and Mills (2008). This proxy, based on financial statement data, has been shown to be highly correlated with simulated rates based on corporate tax return data. ${ }^{7}$ As in the case of TAX $c$, the marginal tax rate is also the residual of a regression of Graham's marginal tax rates on net income. Results are robust to this alternative definition of tax pressures. Both measures, TAX $c$ and the marginal tax rate as per Graham, are expected to create tax related income-shifting incentives that will translate into more conditionally conservative numbers. That is, given current taxation pressures, managers anticipate (defer) the recognition of losses (gains) that otherwise they would have disregarded (recognized) given their general incentives for aggressive accounting practices.

To analyse how taxation drives unconditional conservatism we follow a similar approach to Qiang (2007) and create a proxy (TAX $u$ ) that captures the degree of conformity between tax income and book income. TAX $u$ equals 1 if the average over three years ( $t$ to $t-2)$ of the ratio current income tax (Compustat \#16-\#50) over tax expense (Compustat \#16) is between 0.8 and 1.2, and 0 otherwise. A ratio closer to 1 indicates higher tax-book conformity. TAX $u$ is expected to be associated with unconditional conservatism.

\section{(d) Regulation-Based Incentives for Conditional and Unconditional Conservatism}

To study the association between political costs and conservatism, we create two proxies for political scrutiny. The first one (REG $c$ ) is a firm-specific proxy capturing economywide public scrutiny. We build REG $c$ as an indicator variable taking the value of 1 if the firm pertains to a regulated industry (financials and utilities) in years in which there is a decline in the rate of GDP growth and an increase in the rate of inflation; and 0 otherwise. Pressures from regulators are likely higher in periods of economic downturn, given regulators' asymmetric loss functions. REGc captures these political costs that create incentives for firms under regulators' scrutiny to shift income to periods with a lower public visibility, inducing conditional conservatism. Our second proxy (REGu), identical to the one used by Qiang (2007), is a cross-sectional firm-level proxy with low time-series variation. It measures firms' market share and captures monopoly power. We create REG $u$ as an indicator variable that equals 1 if the ratio of sales deflated

6 Variation in tax rules over time might potentially affect the accounting instruments available to management to delay the recognition of gains or accelerate the recognition of losses, but it is unlikely that they affect managerial incentives, unless they affect tax rates. We are interested in measuring tax-related incentives for conditional conservatism. TAX $c$ captures how these incentives change over time by incorporating the annual highest statutory corporate income tax rate. Thus, changes in tax rules that alter taxation pressures over time are captured by TAX $c$.

7 We download marginal tax rates from Graham's website, which are available since 1980. We thank him for providing the data. 
by (industry total sales/number of firms in the industry) is in the top quartile and 0 otherwise. Industry is based on the two-digit SIC code. REG $u$ is expected to capture incentives for unconditional conservatism.

\section{(e) Unconditional Conservatism Proxies}

The main proxy that we use for unconditional conservatism is a modification of the bias component of Beaver and Ryan (2000). They use the market value of equity as the benchmark to measure conservatism as a persistent downward bias in book value of equity. They measure conservatism using the firm-specific intercept of a regression of book-to-market on firm and time intercepts, and current and lagged stock returns. In their model, returns act as a proxy for current information and the coefficients on returns capture lags in the timing with which book value incorporates the information. However, the method of Beaver and Ryan does not allow for asymmetric incorporation of good and bad news into book value. This introduces noise in the firm-specific intercept because it captures unconditional bias, as well as the conditional bias not captured by the returns coefficients. Like in Qiang (2007), our method allows for the coefficients on returns to be asymmetric to good and bad news by incorporating the Basu (1997) framework into the estimation of the bias component. In particular, we estimate the following model:

$$
\mathrm{BTM}_{i, t}=\alpha_{\iota}+\alpha_{t}+\sum_{j=0}^{6}\left[\beta_{1} D_{i, t-j}+\beta_{2} R_{i, t-j}+\beta_{3} D_{i, t-j} R_{i, t-j}\right]+\mu_{i, t}
$$

where BTM is the book-to-market value of equity ratio measured at the end of the fiscal year, $R$ is the annual stock rate of return of the firm, measured compounding twelve monthly CRSP stock returns ending three months after the last day of fiscal year $t . D$ is a dummy variable that equals 1 in the case of bad news (negative or zero rate of return) and 0 in the case of good news (positive stock rate of return). The firm-specific intercept $\alpha_{i}$ measures the level of unconditional conservatism. To construct annual firm-specific measures of unconditional conservatism, we estimate regression (3) annually using rolling three-year windows. For instance, to obtain the firm-specific measure of unconditional conservatism for year 2005, we run equation (3) pooling firm-year observations for 2005, 2004 and 2003. Then, we use the $\alpha_{i}$ intercepts as our measure of unconditional conservatism for 2005. In addition, Basu (2005) points out that greater unconditional conservatism should lead to a lower intercept in equation (1). For this reason, we add the intercept of annual Basu regressions to our modified bias component. We refer to this final measure of unconditional conservatism as UCons. To facilitate the interpretation of UCons we multiply it by -1 , so that greater values of this measure indicate higher unconditional conservatism.

\section{(iii) The Sample}

We extract accounting data from Compustat, stock market data from CRSP, and macroeconomic data from the web site of the U.S. Federal Reserve. To facilitate the interpretation of the results, we use a constant sample: observations that have missing values for any of our proxies are excluded from the sample. This produces a 
sample that contains 93,838 firm-year observations, corresponding to 10,873 distinct firms, over the 42-year period from 1964 to 2005. To reduce the adverse effect of influential observations, every year we winsorize all continuous variables at the $1^{\text {st }}$ and $99^{\text {th }}$ percentiles. Table 1 Panel A contains sample descriptive statistics. Consistent with prior research, net income is negatively skewed, showing that conditional conservatism exists in our sample. Returns are positively skewed and, as expected, the variation of returns is larger than the variation of earnings. Sample firms present negative returns $42 \%$ of the times. Table 1 Panel B presents Pearson correlation coefficients of main variables. Analysing the correlations between our proxies of the determinants, it can be readily observed that none of them is above 0.2 (the highest correlation is between LEV and $\operatorname{TAX} u$, at -0.166). ${ }^{8}$ This evidence supports our expectation that the proxies capture different underlying phenomena. Finally, and consistent with our expectations, the proxies that capture incentives for reporting conditionally conservative numbers (LITA, TAX $c$, REG $c$ ) show a much more pronounced timeseries variation than the proxies that capture incentives for reporting unconditionally conservative numbers (LITF, TAX $u, \operatorname{REG} u$ ). Specifically, the coefficient of variation of the annual mean of LITA (TAX $c, \operatorname{REG} c)$ is approximately $13(8,12)$ times that of LITF (TAX $u$, REG $u$ ).

\section{EMPIRICAL RESULTS}

\section{(i) Effect of Individual Determinants on Conditional Conservatism}

Table 2, Panels A to E, reports results of running equation (2), where we interact the original Basu (1997) model alternatively with each of our proxies for the conservatism determinants and, finally, with unconditional conservatism. Following Petersen (2008), we use pooled regressions and report $t$-statistics based on standard errors clustered at the firm and year level, which are robust to both heteroskedasticity and within-firm serial correlation. All the $p$-values are based on two-tailed tests. ${ }^{9}$

Panel A shows the results of interacting the original Basu model with our contracting proxies. Focusing on the main coefficient of interest, the $\beta_{31}$ coefficient of model (2), we see that conditional conservatism increases with debt contracting as measured by the interaction between financial leverage and Moody's seasoned Baa corporate bond annual yield (Panel A1, $\beta_{31}=0.059 ; t$-stat $=8.55$ ). This is consistent with high levered firms in years where the corporate bond yield rate is greater providing more conditionally conservative numbers. This result is robust to the use of two alternative proxies for debt contracting: raw leverage and industry-adjusted leverage. With respect to our governance proxy for investors' demand for conditional conservatism arising

8 In the correlation matrix, the use of a constant sample leads to a correlation of -0.006 between TAX $c$ and net income. As described in Section 3, we obtain TAX $c$ as the residuals of a regression of TAX on net income, where we use all available observations. For the whole sample, the correlation between TAX $c$ and net income is 0.000 . The same applies to the mean of TAX $c$ in Panel A: it is not 0 because the table refers to the constant sample.

9 To perform the two-way clustering we use Petersen's (2008) Stata command cluster2, available from his website. We are grateful to him for making the code available. As a sensitivity check we run Fama and MacBeth (1973) mean annual regressions corrected for serial correlation using the Newey and West (1987) procedure. Our results are not sensitive to this alternative specification. As per Petersen's recommendation, in a second sensitivity test, we also include year dummies in the pooled regressions, in addition to clustering at the firm level. This does not change our inferences either. 
Table 1

Variable Definition and Descriptive Statistics of Main Variables

\begin{tabular}{|c|c|c|c|c|c|c|}
\hline $\begin{array}{l}\text { Panel A: Univariate Statistics } \\
\text { Variable Description }\end{array}$ & Var. Name & Mean & Std. Dev. & $P 25$ & Median & P75 \\
\hline Net income & $X$ & 0.038 & 0.221 & 0.022 & 0.066 & 0.112 \\
\hline Returns & $R$ & 0.174 & 0.608 & -0.172 & 0.083 & 0.383 \\
\hline Negative return dummy & $D$ & 0.415 & 0.493 & 0.000 & 0.000 & 1.000 \\
\hline Leverage* average bond yield & LEV & 2.194 & 1.849 & 0.668 & 1.939 & 3.224 \\
\hline Auditor litigation indicator & LITA & 0.362 & 0.481 & 0 & 0 & 1 \\
\hline Firm litigation risk indicator & LITF & 0.268 & 0.443 & 0 & 0 & 1 \\
\hline High marginal tax rate proxy & TAX $c$ & 1.011 & 10.734 & -2.203 & -0.573 & 8.816 \\
\hline $\begin{array}{l}\text { Tax/book income } \\
\text { conformity indicator }\end{array}$ & ТAX $u$ & 0.516 & 0.500 & 0 & 1 & 1 \\
\hline $\begin{array}{l}\text { Regulation indicator: worsening } \\
\text { economic outlook }\end{array}$ & REG $c$ & 0.039 & 0.193 & 0 & 0 & 0 \\
\hline $\begin{array}{l}\text { Regulation indicator: high } \\
\text { market share }\end{array}$ & REG $u$ & 0.379 & 0.485 & 0 & 0 & 1 \\
\hline Unconditional conservatism level & UCons & -0.062 & 0.401 & -0.139 & -0.052 & 0.095 \\
\hline
\end{tabular}

Panel B: Correlation Matrix

\begin{tabular}{|c|c|c|c|c|c|c|c|c|c|c|}
\hline & $X$ & $R$ & $D$ & $L E V$ & LITA & LITF & $T A X c$ & $T A X u$ & $R E G c$ & $R E G u$ \\
\hline$R$ & 0.209 & & & & & & & & & \\
\hline$D$ & -0.229 & -0.618 & & & & & & & & \\
\hline LEV & -0.048 & -0.013 & 0.019 & & & & & & & \\
\hline LITA & -0.065 & 0.009 & -0.032 & 0.049 & & & & & & \\
\hline LITF & 0.019 & 0.107 & -0.012 & 0.008 & 0.061 & & & & & \\
\hline $\operatorname{TAX} c$ & -0.006 & -0.012 & -0.030 & 0.052 & -0.119 & -0.038 & & & & \\
\hline ТАХ $u$ & 0.133 & 0.014 & -0.044 & -0.166 & -0.088 & -0.028 & 0.128 & & & \\
\hline $\mathrm{REG} c$ & 0.021 & 0.006 & -0.047 & 0.030 & 0.033 & -0.042 & -0.047 & -0.041 & & \\
\hline REG $u$ & 0.069 & -0.012 & -0.062 & 0.075 & 0.039 & 0.140 & 0.061 & 0.033 & -0.017 & \\
\hline Ucons & 0.002 & -0.024 & 0.002 & -0.038 & 0.048 & 0.049 & -0.025 & 0.069 & -0.030 & 0.132 \\
\hline
\end{tabular}

Notes:

The sample contains 93,838 firm-year observations corresponding to 10,873 different firms during the period 1964-2005. $X$ is net income, deflated by market value of equity at the beginning of the period. $R$ is the stock rate of return of the firm, measured compounding twelve monthly CRSP stock returns ending three months after fiscal year end. $D$ is a dummy variable that equals 1 in the case of bad news (negative or zero stock rate of return) and 0 in the case of good news (positive stock rate of return). LEV equals Leverage $\times$ Byld, where Leverage is total interest-bearing debt scaled by total assets, measured at the start of the fiscal year, and Byld is Moody's seasoned Baa corporate bond annual yield (in percentage). LITA is an indicator variable that equals 1 if the company's auditor is a big auditing firm (Compustat item \#149 between 1 and 8 ) and if the fiscal year is in a high auditor litigation period, and 0 otherwise. High auditor litigation periods are 1967 to 1975, 1983 to 1995, and 2001 to 2005. LITF is an indicator variable for firm litigation risk that equals 1 if Firm litigation risk is in the fourth quartile and 0 otherwise. Firm litigation risk is a proxy for firm litigation risk defined as the first factor of a principal component analysis of five variables: $\log$ of assets, beta, stock returns, returns skewness and stock turnover. TAX $c$ equals the residuals of a regression of TAX on net income. TAX equals the highest statutory corporate income tax rate if the firm has high marginal tax rate and 0 otherwise. TAX $u$ equals 1 if the average over three years $(t$ to $t-2)$ of the ratio current income tax (Compustat \#16-\#50) over tax expense (Compustat \#16) is between 0.8 and 1.2 , and 0 otherwise. REG $c$ is an indicator variable taking the value of 1 if the firm pertains to a regulated industry (financials and utilities) in years in which there is a decline in the rate of growth of the GDP and an increase in the rate of inflation, and 0 otherwise. REG $u$ is an indicator variable that equals 1 if sales deflated by (industry total sales/number of firms in the industry) is in the top quartile and 0 otherwise. UCons is a firm-year proxy variable for the level of unconditional conservatism, estimated as described in the text, constructed so that higher values indicate higher level of unconditional conservatism. In Panel B, bold figures indicate statistical significance at the $1 \%$ level. 
Table 2

Effect of Individual Determinants on Conditional Conservatism

$$
\begin{gathered}
X_{t}=\beta_{0}+\beta_{1} D_{t}+\beta_{01} \mathrm{DET}_{t}+\beta_{11} D_{t} \mathrm{DET}_{t}+\beta_{2} R_{t}+\beta_{21} R_{t} \mathrm{DET}_{t}+\beta_{3} D_{t} R_{t} \\
+\beta_{31} D_{t} R_{t} \mathrm{DET}_{t}+\mu_{t}
\end{gathered}
$$

\begin{tabular}{|c|c|c|c|c|c|c|c|c|c|}
\hline \multicolumn{10}{|c|}{ Panel A: Contracting Determinants } \\
\hline \multicolumn{4}{|c|}{ Panel A1: Debt Contracting } & & \multicolumn{5}{|c|}{ Panel A2: Managerial Contracting } \\
\hline & & Coef. & $t$-stat & $p$-val & & & Coef. & t-stat & $p$-val \\
\hline Constant & & 0.073 & 10.92 & 0.00 & Constant & & 0.052 & 12.28 & 0.00 \\
\hline$D$ & & 0.004 & 0.60 & 0.55 & $D$ & & -0.003 & -0.80 & 0.43 \\
\hline LEV & & 0.001 & 0.58 & 0.56 & GOV & & -0.012 & -3.47 & 0.00 \\
\hline$D^{*} \mathrm{LEV}$ & & 0.003 & 1.24 & 0.22 & $D^{*} \mathrm{GOV}$ & & 0.000 & -0.06 & 0.95 \\
\hline$R$ & $(+)$ & -0.001 & -0.12 & 0.90 & $R$ & $(+)$ & -0.011 & -1.17 & 0.24 \\
\hline$R^{*} \mathrm{LEV}$ & & 0.005 & 2.09 & 0.04 & $R^{*} \mathrm{GOV}$ & & -0.012 & -1.79 & 0.07 \\
\hline$D^{*} R$ & $(+)$ & 0.249 & 6.31 & 0.00 & $D^{*} R$ & $(+)$ & 0.130 & 5.07 & 0.00 \\
\hline$D^{*} R^{*} \mathrm{LEV}$ & $(+)$ & 0.059 & 8.55 & 0.00 & $D^{*} R^{*} \mathrm{GOV}$ & $(+)$ & 0.066 & 5.60 & 0.00 \\
\hline \multirow{2}{*}{\multicolumn{2}{|c|}{$\begin{array}{l}\text { Adj. } R \text {-squared } \\
\text { N. of obs. }\end{array}$}} & 0.124 & & & Adj. $R$-squa & red & 0.081 & & \\
\hline & & 93,838 & & & N. of obs. & & 10,444 & & \\
\hline
\end{tabular}

\begin{tabular}{|c|c|c|c|c|c|c|c|c|}
\hline \multicolumn{4}{|c|}{ Panel B1: Auditor Litigation } & \multicolumn{5}{|c|}{ Panel B2: Firm-Specific Litigation } \\
\hline & Coef. & t-stat & $p$-val & & & Coef. & $t$-stat & $p$-val \\
\hline Constant & 0.082 & 8.38 & 0.00 & Constant & & 0.072 & 11.17 & 0.00 \\
\hline$D$ & 0.005 & 0.95 & 0.34 & $D$ & & 0.022 & 3.54 & 0.00 \\
\hline LITA & -0.014 & -1.06 & 0.29 & LITF & & 0.013 & 3.06 & 0.00 \\
\hline$D^{*}$ LITA & 0.013 & 1.17 & 0.24 & $D^{*} \mathrm{LITF}$ & & -0.022 & -3.97 & 0.00 \\
\hline$R$ & 0.011 & 0.91 & 0.36 & $R$ & $(+)$ & 0.017 & 1.26 & 0.21 \\
\hline$R^{*}$ LITA & -0.005 & -0.17 & 0.87 & $R^{*} \mathrm{LITF}$ & & -0.015 & -3.07 & 0.00 \\
\hline$D^{*} R$ & 0.316 & 10.87 & 0.00 & $D^{*} R$ & $(+)$ & 0.449 & 9.10 & 0.00 \\
\hline$D^{*} R^{*}$ LITA $\quad(+)$ & 0.217 & 4.31 & 0.00 & $D^{*} R^{*} \mathrm{LITF}$ & $(-)$ & -0.148 & -4.45 & 0.00 \\
\hline $\begin{array}{l}\text { Adj. } R \text {-squared } \\
\text { N. of obs. }\end{array}$ & $\begin{array}{r}0.122 \\
93,838\end{array}$ & & & $\begin{array}{l}\text { Adj. } R \text {-squa } \\
\text { N. of obs. }\end{array}$ & red & $\begin{array}{r}0.115 \\
93,838\end{array}$ & & \\
\hline
\end{tabular}

Panel B: Litigation Determinants

\begin{tabular}{|c|c|c|c|c|c|c|c|}
\hline \multicolumn{4}{|c|}{ Panel C1: High Marginal Tax Rate } & \multicolumn{4}{|c|}{ Panel C2: Tax-Book Conformity } \\
\hline & Coef. & $t$-stat & $p$-val & & Coef. & $t$-stat & $p-v a$ \\
\hline Constant & 0.077 & 11.69 & 0.00 & Constant & 0.057 & 8.20 & 0.00 \\
\hline$D$ & 0.011 & 1.48 & 0.14 & $D$ & 0.009 & 1.27 & 0.20 \\
\hline $\operatorname{TAX} c$ & 0.001 & 1.49 & 0.14 & ТAX $u$ & 0.034 & 7.33 & 0.00 \\
\hline$D^{*} \mathrm{TAX} c$ & 0.002 & 3.64 & 0.00 & $D^{*} \mathrm{TAX} u$ & 0.001 & 0.14 & 0.89 \\
\hline$(+)$ & 0.006 & 0.40 & 0.69 & $(+)$ & 0.006 & 0.44 & 0.66 \\
\hline$R^{*} \mathrm{TAX} c$ & -0.002 & -1.89 & 0.06 & $R^{*} \mathrm{TAX} u$ & 0.012 & 1.61 & 0.11 \\
\hline$D^{*} R$ & 0.407 & 8.26 & 0.00 & $D^{*} R$ & 0.419 & 9.67 & 0.00 \\
\hline$D^{*} R^{*} \operatorname{TAX} c$ & 0.013 & 4.41 & 0.00 & $D^{*} R^{*} \mathrm{TAX} u(-)$ & -0.103 & -4.22 & 0.00 \\
\hline $\begin{array}{l}\text { Adj. } R \text {-squared } \\
\text { N. of obs. }\end{array}$ & $\begin{array}{r}0.122 \\
93,838\end{array}$ & & & $\begin{array}{l}\text { Adj. } R \text {-squared } \\
\text { N. of obs. }\end{array}$ & $\begin{array}{r}0.123 \\
93,838\end{array}$ & & \\
\hline
\end{tabular}

Panel C: Taxation Determinants 
Table 2 (Continued)

Panel D: Regulation Determinants

\begin{tabular}{|c|c|c|c|c|c|c|c|}
\hline \multicolumn{4}{|c|}{ Panel D1: Regulation, Worsening } & \multicolumn{4}{|c|}{ Panel D2: Regulation, High Market Share } \\
\hline & Coef. & $t$-stat & $p$-val & & Coef. & $t$-stat & $p$-val \\
\hline Constant & 0.076 & 9.91 & 0.00 & Constant & 0.073 & 10.12 & 0.00 \\
\hline$D$ & 0.011 & 1.69 & 0.09 & $D$ & 0.006 & 0.88 & 0.38 \\
\hline REG $c$ & 0.006 & 0.72 & 0.47 & REG $u$ & 0.007 & 2.20 & 0.03 \\
\hline$D^{*} \operatorname{REG} c$ & 0.026 & 1.28 & 0.20 & $D^{*} \mathrm{REG} u$ & 0.011 & 2.28 & 0.02 \\
\hline$(+)$ & 0.009 & 0.68 & 0.50 & $(+)$ & 0.009 & 0.75 & 0.46 \\
\hline$R^{*} \mathrm{REG} c$ & 0.033 & 1.55 & 0.12 & $R^{*} \mathrm{REG} u$ & 0.003 & 0.80 & 0.42 \\
\hline$D^{*} R \quad(+)$ & 0.386 & 9.83 & 0.00 & $D^{*} R \quad(+)$ & 0.398 & 10.14 & 0.00 \\
\hline$D^{*} R^{*} \operatorname{REG} c \quad(+)$ & 0.195 & 1.95 & 0.05 & $D^{*} R^{*} \operatorname{REG} u(-)$ & -0.054 & -2.52 & 0.01 \\
\hline $\begin{array}{l}\text { Adj. } R \text {-squared } \\
\text { N. of obs. }\end{array}$ & 0.113 & & & Adj. $R$-squared & 0.113 & & \\
\hline N. of obs. & 93,838 & & & N. of obs. & 93,838 & & \\
\hline
\end{tabular}

\begin{tabular}{|c|c|c|c|c|}
\hline \multicolumn{5}{|c|}{ Panel E: Unconditional Conservatism } \\
\hline & & Coef. & $t$-stat & $p$-val \\
\hline Constant & & 0.076 & 10.88 & 0.00 \\
\hline$D$ & & 0.011 & 1.68 & 0.09 \\
\hline UCons & & -0.016 & -1.55 & 0.12 \\
\hline$D^{*} U$ Cons & & 0.005 & 0.46 & 0.65 \\
\hline$R$ & $(+)$ & 0.006 & 0.48 & 0.63 \\
\hline$R^{*} U$ Cons & & -0.030 & -2.10 & 0.04 \\
\hline$D^{*} R$ & $(+)$ & 0.383 & 9.97 & 0.00 \\
\hline$D^{*} R^{*} U$ Cons & $(-)$ & -0.160 & -4.21 & 0.00 \\
\hline Adj. $R$-squared & & 0.118 & & \\
\hline N. of obs. & & 93,838 & & \\
\hline
\end{tabular}

Notes:

The sample contains 93,838 firm-year observations corresponding to 10,873 different firms during the period 1964-2005. The dependent variable is net income, deflated by market value of equity at the beginning of the period. $R$ is the stock rate of return of the firm, measured compounding twelve monthly CRSP stock returns ending three months after fiscal year end. $D$ is a dummy variable that equals 1 in the case of bad news (negative or zero stock rate of return) and 0 in the case of good news (positive stock rate of return). LEV equals Leverage $\times$ Byld, where Leverage is total interest-bearing debt scaled by total assets, measured at the start of the fiscal year, and Byld is Moody's seasoned Baa corporate bond annual yield (in percentage). LITA is an indicator variable that equals 1 if the company's auditor is a big auditing firm (Compustat item \#149 between 1 and 8) and if the fiscal year is in a high auditor litigation period, and 0 otherwise. High auditor litigation periods are 1967 to 1975,1983 to 1995 , and 2001 to 2005 . LITF is an indicator variable for firm litigation risk that equals 1 if Firm litigation risk is in the fourth quartile and 0 otherwise. Firm litigation risk is a proxy for firm litigation risk defined as the first factor of a principal component analysis of five variables: $\log$ of assets, beta, stock returns, returns skewness and stock turnover. TAX $c$ equals the residuals of a regression of TAX on net income. TAX equals the highest statutory corporate income tax rate if the firm has high marginal tax rate and 0 otherwise. TAX $u$ equals 1 if the average over three years $(t$ to $t-2)$ of the ratio current income tax (Compustat \#16-\#50) over tax expense (Compustat \#16) is between 0.8 and 1.2, and 0 otherwise. REG $c$ is an indicator variable taking the value of 1 if the firm pertains to a regulated industry (financials and utilities) in years in which there is a decline in the rate of growth of the GDP and an increase in the rate of inflation, and 0 otherwise. REG $u$ is an indicator variable that equals 1 if sales deflated by (industry total sales/number of firms in the industry) is in the top quartile and 0 otherwise. UCons is a firm-year proxy variable for the level of unconditional conservatism, estimated as described in the text, constructed so that higher values indicate higher level of unconditional conservatism. GOV measures the level of corporate governance; it is constructed so that higher values indicate better governance (more board independence and fewer anti-takeover provisions).

The $t$-statistics are based on standard errors clustered at the firm and year level (Petersen, 2008), which are robust to both heteroskedasticity and within-firm serial correlation. All the $p$-values are based on two-tailed tests. 
from managerial compensation contracts, Panel A2 shows that stronger governance induces more conditional conservatism $\left(\beta_{31}=0.066 ; t\right.$-stat $\left.=5.60\right)$. This evidence is consistent with the results in Beekes et al. (2004), Ahmed and Duellman (2007) and García Lara et al. (2009) that stronger governance mechanisms impose stricter managerial monitoring and demand increased conditional conservatism. ${ }^{10}$

Regarding litigation risk driven incentives for conservatism, Panel B shows that conditional conservatism increases with LITA (Panel B1, $\beta_{31}=0.217$; $t$-stat $=4.31$ ). LITA measures auditor's litigation risk exposure, as measured by combining litigation risk period with auditor size (size is a proxy both of auditor reputation concerns and the deep pockets hypothesis: large auditors suffering greater losses in case of audit failure, both in terms of reputation and wealth). LITA allows for cross-sectional and time-series variation in auditors' litigation exposure and is therefore expected to induce conditional conservatism. This result holds when we use a pure time-series proxy for litigation like in Basu (1997) and Holthausen and Watts (2001). On the other hand, consistent with our expectation that firm-level litigation risk with little time-series variation induces only unconditional conservatism, Panel B2 shows a negative relation between LITF and conditional conservatism $\left(\beta_{31}=-0.148 ; t\right.$-stat $\left.=-4.45\right)$.

With respect to taxation and regulation, results indicate that our proxies for taxation pressures (TAX $c$ ) and regulation pressures (REG $c$ ) appear to correctly capture incentives for conditional conservatism, as greater values of these proxies are associated to increases in the timeliness of income to bad news (Panel C1, $\beta_{31}=0.013$; $t$-stat $=$ 4.41 , and Panel D1, $\beta_{31}=0.195 ; t$-stat $=1.95$, respectively). Our taxation results are robust to the use of the simulated marginal tax rates proposed by Graham (1996). Panels C2 and D2 show that firm-level proxies for taxation and regulation that do not particularly change over time (TAX $u$ and REG $u$ ) are not associated with increases in conditional conservatism (in fact, we observe significantly negative $\beta_{31}$ coefficients), consistent with firm-specific time-invariant taxation and regulation pressures inducing mainly unconditional conservatism.

Finally, Panel E shows that, as expected, the timeliness of earnings to economic losses decreases when unconditional conservatism is high $\left(\beta_{31}=-0.160 ; t\right.$-stat $\left.=-4.21\right)$. Greater unconditional conservatism is also associated with reductions in the timeliness of earnings to good news (Panel E, $\beta_{21}=-0.030 ; t$-stat $=-2.10$ ), which suggests that unconditional conservatism generally dampens the timeliness of accounting income. Although Basu (2005) argues that the intercepts of Basu regressions are also capturing unconditional conservatism, we rely on the more direct test in Panel $\mathrm{E}$ to analyse the relation between conditional and unconditional conservatism, as the intercepts are also a function of cost of capital (Pope and Walker, 1999) and Basu (1997) also argues that they capture the delayed incorporation in earnings of good news from prior periods. For these reasons, intercepts do not yield an unambiguous interpretation.

The evidence in Table 2 is therefore consistent with our expectation that conditional conservatism is positively associated to contracting, litigation, taxation, and regulation, even if litigation, taxation and regulation primarily induce unconditional conservatism. Put together, these results strongly indicate that all four determinants create incentives

10 In Panel A2, GOV is only available for 10,444 firm-year observations because the data to construct this proxy is drawn from Execucomp, which starts in 1992. For this reason, we exclude GOV from the rest of analyses. 
for conditional conservatism, as identified by Watts (2003). Also, our evidence suggests that even though time-invariant taxation and regulation pressures likely result in the implementation of unconditionally conservative accounting policies, this stock of unconditional conservatism does not exhaust the opportunities (or incentives) for successful conditional conservatism in later periods.

To assess the economic significance of higher exposure to each of the four determinants of conditional conservatism, we compute the percentage increase in asymmetric timeliness when the exposure to a determinant changes from a low bound to a high bound. For LEV and TAX $c$ the low (high) bound is defined as percentile 25 (percentile 75). For the indicator variables LITA and REG $c$ the low bound is 0 and the high bound is 1 . Therefore, using the coefficient estimates from Panels A1$\mathrm{D} 1$, we compute the change in $\left(\beta_{3}+\beta_{31} * \mathrm{DET}\right)$ when the determinant moves from the low bound to the high bound. For LEV, the increase in asymmetric timelines is $0.151(52.4 \%)$; for LITA is $0.217(68.8 \%)$; for TAX $c$ is $0.139(36.7 \%)$; and for REG $c$ is $0.195(50.5 \%)$. The percentage increase is computed by dividing the change in asymmetric timeliness by its value at the lower bound. This ratio-based definition of the increase in conditional conservatism presents the advantage that it isolates the measure from the possible effects of cost of capital on coefficient $\beta_{3}$ (Pope and Walker, 1999). The conclusion from these estimates is that, on average, firms' sensitivity to bad news increases by approximately $50 \%$ when the exposure to the determinant of conditional conservatism changes from the low bound to the high bound.

\section{(ii) Joint Effect of all Determinants on Conditional Conservatism}

The analysis of Table 2 however, fails to demonstrate whether each of the determinants is associated with incrementally significant effects on conditional conservatism or whether some of them merely capture the same underlying phenomenon. As a second test, we consider the effects of all the determinants in a single test. To do so, we interact the Basu specification with all the determinants and unconditional conservatism in the same regression. Table 3 Panel A reports results of this test. The results confirm those previously reported in Table 2, that is, conditional conservatism increases with contracting, as well as with litigation, taxation and regulatory pressures that create income-shifting incentives and thus induce conditional conservatism. Firm-specific time invariant litigation, taxation and regulatory pressures are negatively associated to conditional conservatism, consistent with these pressures mainly resulting in the implementation of unconditionally conservative accounting practices.

From these results we conclude that each of these determinants is associated with incrementally significant effects on conditional conservatism, and we can discard the alternative explanation that they merely capture the same underlying phenomenon. The $\beta_{31}$ coefficient magnitudes from Table 2 are very similar to those reported in Table 3 Panel A, suggesting that each of the economic determinants is fairly orthogonal to the other variables. The last column of Panel A presents the evolution in the adjusted $R$-squared as we incorporate additional determinants to the model. For the simple Basu model, we obtain an adjusted $R$-squared of 0.111 . The explanatory power of our model increases monotonically as we add the determinants, up to 0.169 for the full model. 
Table 3

Joint Model of all the Determinants

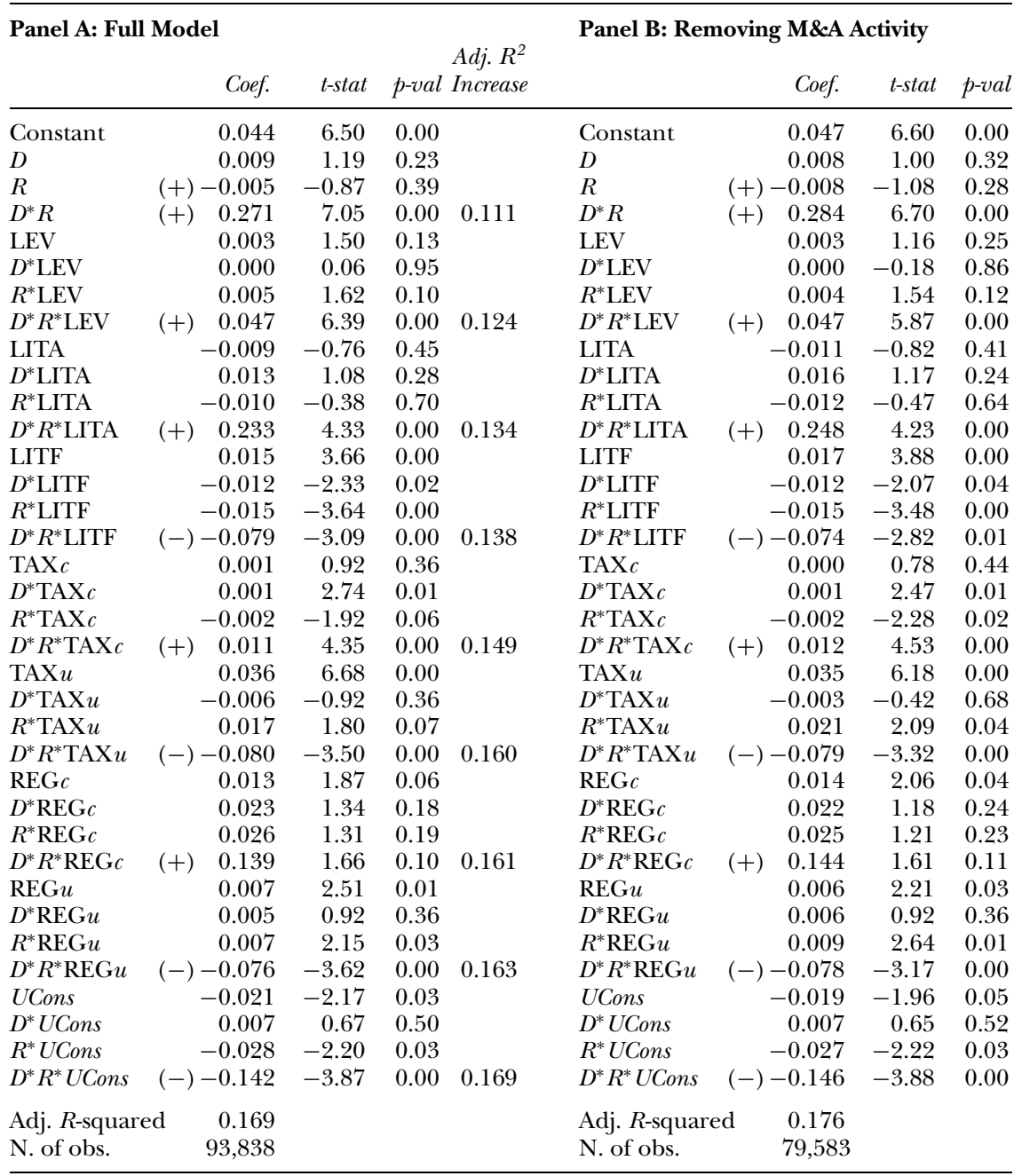

Notes:

The sample contains a maximum of 93,838 firm-year observations corresponding to 10,873 different firms during the period 1964-2005. In Panel B, we remove firm-year observations in which mergers or acquisitions (M\&A) took place. The dependent variable is net income, deflated by market value of equity at the beginning of the period. $R$ is the stock rate of return of the firm, measured compounding twelve monthly CRSP stock returns ending three months after fiscal year end. $D$ is a dummy variable that equals 1 in the case of bad news (negative or zero stock rate of return) and 0 in the case of good news (positive stock rate of return). LEV equals Leverage $\times$ Byld, where Leverage is total interest-bearing debt scaled by total assets, measured at the start of the fiscal year, and Byld is Moody's seasoned Baa corporate bond annual yield (in percentage). LITA is an indicator variable that equals 1 if the company's auditor is a big auditing firm (Compustat item \#149 between 1 and 8) and if the fiscal year is in a high auditor litigation period, and 0 otherwise. High auditor litigation periods are 1967 to 1975,1983 to 1995 , and 2001 to 2005. LITF 
Table 3 (Continued)

is an indicator variable for firm litigation risk that equals 1 if Firm litigation risk is in the fourth quartile and 0 otherwise. Firm litigation risk is a proxy for firm litigation risk defined as the first factor of a principal component analysis of five variables: $\log$ of assets, beta, stock returns, returns skewness and stock turnover. TAX $c$ equals the residuals of a regression of TAX on net income. TAX equals the highest statutory corporate income tax rate if the firm has high marginal tax rate and 0 otherwise. TAX $u$ equals 1 if the average over three years ( $t$ to $t-2)$ of the ratio current income tax (Compustat \#16-\#50) over tax expense (Compustat \#16) is between 0.8 and 1.2, and 0 otherwise. REG $c$ is an indicator variable taking the value of 1 if the firm pertains to a regulated industry (financials and utilities) in years in which there is a decline in the rate of growth of the GDP and an increase in the rate of inflation, and 0 otherwise. REGu is an indicator variable that equals 1 if sales deflated by (industry total sales/number of firms in the industry) is in the top quartile and 0 otherwise. UCons is a firm-year proxy variable for the level of unconditional conservatism, estimated as described in the text, constructed so that higher values indicate higher level of unconditional conservatism.

The $t$-statistics are based on standard errors clustered at the firm and year level (Petersen, 2008), which are robust to both heteroskedasticity and within-firm serial correlation. All the $p$-values are based on two-tailed tests.

These test results are robust to the use of the already described alternative proxies for the conservatism determinants. ${ }^{11}$

\section{(iii) Sensitivity Tests}

To check the robustness of our findings, we run a series of sensitivity tests to control for: (1) the inclusion of observations affected by mergers and acquisitions; (2) the effect of information asymmetries on conditional conservatism; (3) the differential demand for conservatism that originates from private vs. public debt contracts; and (4) the effects of the interaction between leverage and taxation. In addition, (5) we re-examine the association between conditional conservatism and the determinants, using changes in their levels, rather than the original determinants; and (6) we analyse the effect of removing interest and tax expense from the dependent variable, net income, as these two earnings components are endogenous to conservatism forces.

\section{(a) Effect of Mergers and Acquisitions}

We control for the potentially detrimental effect that major non-recurring transactions, such as mergers or acquisitions, can have on our conservatism measures and independent variables (Hribar and Collins, 2002). Table 3 Panel B presents results of running our joint model excluding firm-year observations in which mergers or acquisitions (M\&A) took place. The sample is reduced to 79,583 firm-year observations due to this procedure. All our main inferences remain identical.

11 Given the large number of regressors, it is prudent to test for the presence of multicollinearity. To do so, we compute the variance inflation factors (VIF) of the independent variables. The only regressor with a VIF larger than 10 , the cut off value suggested by some analysts, is $D(\mathrm{VIF}=13.32)$. After removing $D$ from the regression, the highest VIF is 8.97 and there are virtually no changes in the coefficients and standard errors estimated for the rest of independent variables. This clearly shows that multicollinearity is not driving our inferences. 
(b) Information Asymmetry and Conditional Conservatism

As an additional sensitivity analysis, and given the evidence provided by LaFond and Watts (2008) that managers increase conditional conservatism to ameliorate the negative effects of information asymmetries, we include in the regression in Table 3 the bid-ask spread (BAS), a proxy for information asymmetries. BAS is an indicator variable that takes on the value of 1 if the average bid-ask spread of the firm at $t-1$ is in the top quartile of the distribution, and 0 otherwise. The bid-ask spread is defined as the annual average of daily closing bid-ask spread, scaled by the midpoint between the bid and the ask. Table 4 Panel A provides results of including BAS in the full model with all the determinants. Consistent with prior evidence in LaFond and Watts (2008), information asymmetry is positively associated to conditional conservatism $\left(D^{*} R^{*} \mathrm{BAS}=0.127, t\right.$-stat $\left.=4.25\right)$, suggesting that conditional conservatism appears as a reaction to information asymmetries. All the determinants remain significant and have the expected signs. Thus, our inferences are not affected by including this additional regressor, suggesting that the economic determinants capture incentives for implementing conditionally conservative accounting policies in addition to those driven by information asymmetries.

(c) Private vs. Public Debt-Contracting, and the Effect of Taxation on Debt-Incentives

Leftwich (1983) reports that private debt contracts undo many aggressive accounting choices in covenant calculations, which likely indicates that private debt-holders require more conservative accounting than provided by GAAP, suggesting a more flexible use of GAAP figures in private debt contracts. Thus, our debt-contracting proxy (LEV) may act as an upwardly biased proxy for public debt contracts that rely on reported figures for evaluating covenant breaches. As a sensitivity check, we repeat the analysis of Table 2 Panel A1, including a proxy for private debt contracts (PRIVDBT) in the model. PRIVDBT is the ratio, in percentage, of private long-term debt (Compustat \#81 + $\# 83+\# 84)$ to total long-term debt (Compustat \#81 +\#82+\#83+\#84). Table 4 Panel B presents the results of this test. Both LEV and PRIVDBT are positively associated to conditional conservatism $\left(D^{*} R^{*} \mathrm{LEV}=0.055, t\right.$-stat $=7.84 ; D^{*} R^{*} \mathrm{PRIVDBT}=0.131$, $t$-stat $=3.53)$. In fact, the evidence shows that the greater the proportion of private debt, the greater the conditional conservatism. This evidence suggests that, if anything, flexible use of GAAP numbers in private debt contracts results in an additional demand for conditional conservatism.

Regarding our debt-contracting tests, time-series variation in income tax rates likely also affects the attractiveness of debt, because interest tax deductions may become more valuable whenever there is a change in tax rates. As an additional test of the association between debt contracting and conditional conservatism, we interact our debt-contracting proxy with a time-series proxy of tax pressures (TAX). TAX equals the highest statutory corporate income tax rate if the firm has a high marginal tax rate and 0 otherwise. Results of this test are presented in Table 4 Panel C. The evidence suggests that whenever income taxes are higher, the association between conditional conservatism and debt-contracting becomes increasingly positive $\left(\beta_{31}=0.124\right.$; $t$-stat $=5.15)$, consistent with the interpretation that taxation can impact the association between conditional conservatism and debt-contracting. 
Table 4

Robustness Tests

\begin{tabular}{|c|c|c|c|c|c|c|c|c|}
\hline \multicolumn{4}{|c|}{ Panel A: Information Asymmetry Control } & \multicolumn{5}{|c|}{ Panel B: Effect of Private Debt Proportion } \\
\hline & Coef. & $t$-stat & $p$-val & & & Coef. & $t$-stat & p-val \\
\hline Constant & 0.049 & 7.12 & 0.00 & Constant & & 0.093 & 11.73 & 0.00 \\
\hline$D$ & 0.009 & 1.21 & 0.23 & $D$ & & -0.002 & -0.17 & 0.86 \\
\hline$(+)$ & 0.014 & 2.56 & 0.01 & $R$ & $(+)$ & 0.022 & 1.64 & 0.10 \\
\hline$D^{*} R$ & 0.193 & 6.22 & 0.00 & $D^{*} R$ & $(+)$ & 0.098 & 2.30 & 0.02 \\
\hline LEV & 0.003 & 1.56 & 0.12 & LEV & & 0.001 & 0.23 & 0.82 \\
\hline$D^{*} \mathrm{LEV}$ & 0.001 & 0.29 & 0.78 & $D^{*} \mathrm{LEV}$ & & 0.002 & 1.00 & 0.32 \\
\hline$R^{*} \mathrm{LEV}$ & 0.004 & 1.57 & 0.12 & $R^{*} \mathrm{LEV}$ & & 0.004 & 2.07 & 0.04 \\
\hline$D^{*} R^{*} \mathrm{LEV}$ & 0.050 & 7.16 & 0.00 & $D^{*} \mathrm{R}^{*} \mathrm{LEV}$ & $(+)$ & 0.055 & 7.84 & 0.00 \\
\hline LITA & -0.012 & -0.95 & 0.34 & PRIVDBT & & -0.020 & -3.06 & 0.00 \\
\hline$D^{*}$ LITA & 0.013 & 1.14 & 0.25 & $D^{*}$ PRIVDBT & & 0.004 & 0.50 & 0.62 \\
\hline$R^{*}$ LITA & -0.010 & -0.43 & 0.67 & $R^{*}$ PRIVDBT & & -0.015 & -1.15 & 0.25 \\
\hline$D^{*} R^{*}$ LITA & 0.232 & 4.47 & 0.00 & $D^{*} R^{*}$ PRIVDBT & $(+)$ & 0.131 & 3.53 & 0.00 \\
\hline LITF & 0.016 & 3.78 & 0.00 & & & & & \\
\hline$D^{*} \mathrm{LITF}$ & -0.010 & -2.14 & 0.03 & Adj. $R$-squared & & 0.122 & & \\
\hline$R^{*} \mathrm{LITF}$ & -0.013 & -4.32 & 0.00 & N. of obs. & & 68,358 & & \\
\hline$D^{*} R^{*}$ LITF & -0.087 & -3.40 & 0.00 & & & & & \\
\hline $\mathrm{TAX} c$ & 0.000 & 0.81 & 0.42 & \multicolumn{5}{|c|}{ Panel C: Interaction of LEV with TAX } \\
\hline$D^{*}$ TAX $c$ & 0.001 & 2.76 & 0.01 & & & Coef. & $t$-stat & $p$-val \\
\hline$R^{*} \mathrm{TAX} c$ & -0.002 & -2.15 & 0.03 & & & & & \\
\hline$D^{*} R^{*} \operatorname{TAX} c$ & 0.011 & 4.45 & 0.00 & Constant & & 0.068 & 10.54 & 0.00 \\
\hline ТАХ $u$ & 0.035 & 6.48 & 0.00 & $D$ & & 0.005 & 0.85 & 0.40 \\
\hline$D^{*}$ ТАХ $u$ & -0.006 & -0.91 & 0.36 & LEV*TAX & & 0.009 & 1.60 & 0.11 \\
\hline$R^{*} \mathrm{TAX} u$ & 0.015 & 1.64 & 0.10 & $D^{*} \mathrm{LEV}^{*} \mathrm{TAX}$ & & 0.008 & 1.56 & 0.12 \\
\hline$D^{*} R^{*} \mathrm{TAX} u \quad(-)$ & -0.077 & -3.35 & 0.00 & $R$ & $(+)$ & -0.003 & -0.37 & 0.72 \\
\hline $\operatorname{REG} c$ & 0.011 & 1.54 & 0.12 & $R^{*} \mathrm{LEV}^{*} \mathrm{TAX}$ & & 0.016 & 2.55 & 0.01 \\
\hline$D^{*} \operatorname{REG} c$ & 0.021 & 1.22 & 0.22 & $D^{*} R$ & $(+)$ & 0.276 & 6.70 & 0.00 \\
\hline$R^{*} \mathrm{REG} c$ & 0.022 & 1.12 & 0.26 & $D^{*} R^{*} \mathrm{LEV}^{*} \mathrm{TAX}$ & $(+)$ & 0.124 & 5.15 & 0.00 \\
\hline$D^{*} R^{*} \operatorname{REG} c$ & 0.129 & 1.55 & 0.12 & & & & & \\
\hline REG $u$ & 0.002 & 0.76 & 0.45 & Adj. $R$-squared & & 0.121 & & \\
\hline$D^{*}$ REG $u$ & 0.005 & 0.78 & 0.43 & N. of obs. & & 93,838 & & \\
\hline$R^{*} \mathrm{REG} u$ & -0.004 & -0.87 & 0.38 & & & & & \\
\hline$D^{*} R^{*} \operatorname{REG} u \quad(-)$ & -0.032 & -1.54 & 0.12 & & & & & \\
\hline UCons & -0.023 & -2.46 & 0.01 & & & & & \\
\hline$D^{*} U$ Cons & 0.007 & 0.75 & 0.46 & & & & & \\
\hline$R^{*}$ UCons & -0.025 & -1.83 & 0.07 & & & & & \\
\hline$D^{*} R^{*} U$ Cons $(-)$ & -0.149 & -4.30 & 0.00 & & & & & \\
\hline BAS & -0.048 & -4.73 & 0.00 & & & & & \\
\hline$D^{*} \mathrm{BAS}$ & -0.001 & -0.06 & 0.95 & & & & & \\
\hline$R^{*} \mathrm{BAS}$ & -0.030 & -2.66 & 0.01 & & & & & \\
\hline$D^{*} R^{*} \mathrm{BAS}$ & 0.127 & 4.25 & 0.00 & & & & & \\
\hline N. of obs. & 93,067 & & & & & & & \\
\hline Adj. $R$-squared & 0.183 & & & & & & & \\
\hline
\end{tabular}

Notes:

The sample contains firm-year observations corresponding to 10,873 different firms during the period 1964-2005. The dependent variable is net income, deflated by market value of equity at the beginning of the period. $R$ is the stock rate of return of the firm, measured compounding twelve monthly CRSP stock returns ending three months after fiscal year end. $D$ is a dummy variable that equals 1 in the case of bad news (negative or zero stock rate of return) and 0 in the case of good news (positive stock rate 
of return). LEV equals Leverage $\times$ Byld, where Leverage is total interest-bearing debt scaled by total assets, measured at the start of the fiscal year, and Byld is Moody's seasoned Baa corporate bond annual yield (in percentage). LITA is an indicator variable that equals 1 if the company's auditor is a big auditing firm (Compustat item \#149 between 1 and 8) and if the fiscal year is in a high auditor litigation period, and 0 otherwise. High auditor litigation periods are 1967 to 1975,1983 to 1995 , and 2001 to 2005 . LITF is an indicator variable for firm litigation risk that equals 1 if Firm litigation risk is in the fourth quartile and 0 otherwise. Firm litigation risk is a proxy for firm litigation risk defined as the first factor of a principal component analysis of five variables: $\log$ of assets, beta, stock returns, returns skewness and stock turnover. TAX $c$ equals the residuals of a regression of TAX on net income. TAX equals the highest statutory corporate income tax rate if the firm has high marginal tax rate and 0 otherwise. TAX $u$ equals 1 if the average over three years ( $t$ to $t-2)$ of the ratio current income tax (Compustat \#16-\#50) over tax expense (Compustat \#16) is between 0.8 and 1.2, and 0 otherwise. REG $c$ is an indicator variable taking the value of 1 if the firm pertains to a regulated industry (financials and utilities) in years in which there is a decline in the rate of growth of the GDP and an increase in the rate of inflation, and 0 otherwise. REG $u$ is an indicator variable that equals 1 if sales deflated by (industry total sales/number of firms in the industry) is in the top quartile and 0 otherwise. UCons is a firm-year proxy variable for the level of unconditional conservatism, estimated as described in the text, constructed so that higher values indicate higher level of unconditional conservatism. BAS is an indicator variable that takes on the value of 1 if the average bid-ask spread of the firm at $t-1$ is in the top quartile of the distribution, and 0 otherwise. The bid-ask spread is defined as the annual average of daily closing bid-ask spread, scaled by the midpoint between the bid and the ask. The bid-ask spread is a proxy for the degree of information asymmetry. PRIVDBT is the ratio, in percentage, of private long-term debt (Compustat \#81 + \#83+\#84) to total long-term debt (Compustat \#81 + \#82+\#83+\#84).

The $t$-statistics are based on standard errors clustered at the firm and year level (Petersen, 2008), which are robust to both heteroskedasticity and within-firm serial correlation. All the $p$-values are based on two-tailed tests.

\section{(d) Changes in the Level of the Determinants of Conditional Conservatism}

As a robustness check, we examine the association between changes in each of the determinants (rather than the levels) and conditional conservatism. We focus on changes in the main variables of interest, i.e., changes in our proxies for incentives for conditional conservatism: $\triangle \mathrm{LEV}, \triangle \mathrm{LITA}, \triangle \mathrm{TAX} c$ and $\triangle \mathrm{REC} c$. To increase the power of our tests we define $\Delta$ as the change from $t-3$ to $t$. Table 5 Panels A to D contains the results of running model (2), where we interact the original Basu (1997) model alternatively with each of these proxies, measured as changes in the levels of the original determinants. The results confirm the previously reported evidence: conditional conservatism appears as a reaction to changes in the level of contracting incentives (Panel A, $\beta_{31}=0.036 ; t$-stat $=2.27$ ); litigation-risk related incentives $\left(\right.$ Panel B, $\beta_{31}=0.143 ; t$-stat $\left.=2.35\right)$; tax pressures (Panel C, $\beta_{31}=0.016$; $t$-stat $=$ $4.72) ;{ }^{12}$ and regulation incentives (Panel D, $\beta_{31}=0.199 ; t$-stat $=2.28$ ). Including all four determinants in the same regression, like we did in Table 3, produces the same inferences.

\section{(e) Removing from Net Income the Effect of Interest and Tax Expense}

We use net income as the earnings construct in our tests. Net income may already reflect tax (via tax charge) and cost of debt (via interest expense). Thus, our dependent variable may incorporate some of the tax and debt contracting effects we aim to

12 When the tax variable, TAX $c$ is computed using Graham's (2006) marginal tax rates, the coefficient on $D^{*} R^{*} \Delta \mathrm{TAX} c$ is $0.021, t$-stat $=4.87$. 
Table 5

Robustness Tests

Effect of Changes in Level of Determinants of Conditional Conservatism $X_{t}=\beta_{0}+\beta_{1} D_{t}+\beta_{01} \Delta \mathrm{DET}_{t}+\beta_{11} D_{t} \Delta \mathrm{DET}_{t}+\beta_{2} R_{t}+\beta_{21} R_{t} \Delta \mathrm{DET}_{t}+\beta_{3} D_{t} R_{t}$ $+\beta_{31} D_{t} R_{t} \Delta \mathrm{DET}_{t}+\mu_{t}$

\begin{tabular}{|c|c|c|c|c|c|c|c|c|c|}
\hline \multirow{2}{*}{\multicolumn{3}{|c|}{$\begin{array}{r}\text { Panel A: Debt Contracting } \\
\text { Coef. }\end{array}$}} & \multicolumn{7}{|c|}{ Panel B: Auditor Litigation } \\
\hline & & & \multirow{2}{*}{$\begin{array}{c}t \text {-stat } \\
9.51\end{array}$} & \multirow{2}{*}{$\frac{p-v a l}{0.00}$} & \multicolumn{3}{|c|}{ Coef. } & \multirow{2}{*}{$\begin{array}{c}t \text {-stat } \\
9.23\end{array}$} & \multirow{2}{*}{$\frac{p \text {-val }}{0.00}$} \\
\hline Constant & & 0.077 & & & Constant & & 0.076 & & \\
\hline$D$ & & 0.019 & 2.65 & 0.01 & $D$ & & 0.018 & 2.94 & 0.00 \\
\hline$\triangle \mathrm{LEV}$ & & 0.001 & 0.20 & 0.84 & $\Delta$ LITA & & 0.001 & 0.06 & 0.96 \\
\hline$D^{*} \Delta \mathrm{LEV}$ & & -0.001 & -0.28 & 0.78 & $D^{*} \Delta \mathrm{LITA}$ & & 0.014 & 1.31 & 0.19 \\
\hline$R$ & $(+)$ & 0.012 & 0.88 & 0.38 & $R$ & $(+)$ & 0.017 & 1.74 & 0.08 \\
\hline$R^{*} \Delta \mathrm{LEV}$ & & -0.002 & -0.48 & 0.63 & $R^{*} \Delta \mathrm{LITA}$ & & -0.022 & -1.02 & 0.31 \\
\hline$D^{*} R$ & $(+)$ & 0.419 & 8.19 & 0.00 & $D^{*} R$ & $(+)$ & 0.404 & 8.90 & 0.00 \\
\hline$D^{*} R^{*} \Delta \mathrm{LEV}$ & $(+)$ & 0.036 & 2.27 & 0.02 & $D^{*} R^{*} \Delta \mathrm{LITA}$ & $(+)$ & 0.143 & 2.35 & 0.02 \\
\hline Adj. $R$-square & & 0.112 & & & Adj. $R$-squared & & 0.113 & & \\
\hline \multicolumn{5}{|c|}{ Panel C: High Marginal Tax Rate } & \multicolumn{5}{|c|}{$\begin{array}{l}\text { Panel D: Regulation, Worsening } \\
\text { Economic Outlook }\end{array}$} \\
\hline & & Coef. & $t$-stat & $p$-val & & & Coef. & $t$-stat & $p$-val \\
\hline Constant & & 0.076 & 9.44 & 0.00 & Constant & & 0.077 & 9.53 & 0.00 \\
\hline$D$ & & 0.023 & 3.23 & 0.00 & $D$ & & 0.020 & 2.75 & 0.01 \\
\hline$\triangle \mathrm{TAX} c$ & & -0.002 & -2.23 & 0.03 & $\triangle \mathrm{REG} c$ & & 0.012 & 0.85 & 0.39 \\
\hline$D^{*} \Delta \mathrm{TAX} c$ & & 0.003 & 5.88 & 0.00 & $D^{*} \Delta \mathrm{REG} c$ & & 0.430 & 8.55 & 0.00 \\
\hline$R$ & $(+)$ & 0.010 & 0.69 & 0.49 & $R$ & $(+)$ & 0.001 & 0.18 & 0.86 \\
\hline$R^{*} \Delta \mathrm{TAX} c$ & & -0.002 & -4.29 & 0.00 & $R^{*} \Delta \mathrm{REG} c$ & & 0.012 & 0.71 & 0.48 \\
\hline$D^{*} R$ & $(+)$ & 0.446 & 8.88 & 0.00 & $D^{*} R$ & $(+)$ & 0.006 & 0.29 & 0.77 \\
\hline$D^{*} R^{*} \Delta \mathrm{TAX} c$ & $(+)$ & 0.016 & 4.72 & 0.00 & $D^{*} R^{*} \Delta \mathrm{REG} c$ & $(+)$ & 0.199 & 2.28 & 0.02 \\
\hline Adj. $R$-square & & 0.146 & & & Adj. $R$-squared & & 0.111 & & \\
\hline
\end{tabular}

Notes:

The sample contains 58,926 firm-year observations corresponding to 10,873 different firms during the period 1964-2005. The dependent variable is net income, deflated by market value of equity at the beginning of the period. $\Delta$ indicates change from year $t-3$ to $t . R$ is the stock rate of return of the firm, measured compounding twelve monthly CRSP stock returns ending three months after fiscal year end. $D$ is a dummy variable that equals 1 in the case of bad news (negative or zero stock rate of return) and 0 in the case of good news (positive stock rate of return). LEV equals Leverage $\times$ Byld, where Leverage is total interest-bearing debt scaled by total assets, measured at the start of the fiscal year, and Byld is Moody's seasoned Baa corporate bond annual yield (in percentage). LITA is an indicator variable that equals 1 if the company's auditor is a big auditing firm (Compustat item \#149 between 1 and 8) and if the fiscal year is in a high auditor litigation period, and 0 otherwise. High auditor litigation periods are 1967 to 1975,1983 to 1995 , and 2001 to 2005. TAX $c$ equals the residuals of a regression of TAX on net income. TAX equals the highest statutory corporate income tax rate if the firm has high marginal tax rate and 0 otherwise. REG $c$ is an indicator variable taking the value of 1 if the firm pertains to a regulated industry (financials and utilities) in years in which there is a decline in the rate of growth of the GDP and an increase in the rate of inflation, and 0 otherwise.

The $t$-statistics are based on standard errors clustered at the firm and year level (Petersen, 2008), which are robust to both heteroskedasticity and within-firm serial correlation. All the $p$-values are based on two-tailed tests.

measure. As a sensitivity analysis, we study the association between conservatism, taxation and debt contracting using as the dependent variable in model (2) net income before interest and tax expense (EBIT). By using EBIT as the dependent variable, we eliminate the effects of earnings components that are endogenous to 
Table 6

Robustness Tests

Removing from Net Income the Effect of Interest and Tax Expense $\mathrm{EBIT}_{t}=\beta_{0}+\beta_{1} D_{t}+\beta_{01} \mathrm{DET}_{t}+\beta_{11} D_{t} \mathrm{DET}_{t}+\beta_{2} R_{t}+\beta_{21} R_{t} \mathrm{DET}_{t}+\beta_{3} D_{t} R_{t}$ $+\beta_{31} D_{t} R_{t} \mathrm{DET}_{t}+\mu_{t}$

\begin{tabular}{|c|c|c|c|c|c|c|c|c|}
\hline & \multirow{3}{*}{$\frac{p \text {-val }}{0.00}$} & \multicolumn{4}{|c|}{ Panel B: High Marginal Tax Rate } \\
\hline \multicolumn{4}{|c|}{$\begin{array}{c}\text { Panel A: Debt Contracting } \\
\text { Coef. }\end{array}$} & & & Coef. & $t$-stat & \multirow{2}{*}{$\frac{p \text {-val }}{0.00}$} \\
\hline Constant & & 0.096 & 8.88 & & Constant & 0.190 & 12.15 & \\
\hline$D$ & & -0.003 & -0.37 & 0.71 & $D$ & 0.000 & -0.04 & 0.97 \\
\hline LEV & & 0.044 & 10.16 & 0.00 & $\mathrm{TAX} c$ & 0.002 & 2.25 & 0.03 \\
\hline$D^{*} \mathrm{LEV}$ & & 0.002 & 0.62 & 0.54 & $D^{*} \mathrm{TAX} c$ & 0.002 & 1.96 & 0.05 \\
\hline$R$ & $(+)$ & 0.006 & 0.44 & 0.66 & $R$ & 0.044 & 1.59 & 0.11 \\
\hline$R^{*} \mathrm{LEV}$ & & 0.019 & 3.67 & 0.00 & $R^{*} \mathrm{TAX} c$ & -0.002 & -1.47 & 0.14 \\
\hline$D^{*} R$ & $(+)$ & 0.301 & 7.11 & 0.00 & $D^{*} R$ & 0.407 & 8.03 & 0.00 \\
\hline$D^{*} R^{*} \mathrm{LEV}$ & $(+)$ & 0.048 & 4.76 & 0.00 & $D^{*} R^{*} \mathrm{TAX} c$ & 0.013 & 4.06 & 0.00 \\
\hline Adj. $R$-sque & red & 0.180 & & & Adj. $R$-squared & 0.106 & & \\
\hline
\end{tabular}

\section{Panel C: Tax-Book Conformity}

\begin{tabular}{|c|c|c|c|}
\hline & Coef. & $t$-stat & $p-v a l$ \\
\hline Constant & 0.178 & 11.02 & 0.00 \\
\hline$D$ & -0.006 & -0.52 & 0.6 \\
\hline $\mathrm{TAX} u$ & 0.025 & 2.98 & 0. \\
\hline$D^{*} \mathrm{TAX} u$ & 0.008 & 1.08 & 0.2 \\
\hline$R$ & 0.042 & 1.71 & 0.09 \\
\hline$R^{*} \mathrm{TAX} u$ & 0.010 & 0.94 & $0 .{ }^{2}$ \\
\hline$D^{*} R$ & 0.417 & 9.83 & 0.0 \\
\hline$D^{*} R^{*} \mathrm{TAX} u$ & -0.072 & -2.73 & 0.01 \\
\hline Adj. $R$-squared & 0.104 & & \\
\hline
\end{tabular}

Notes:

The sample contains 93,838 firm-year observations corresponding to 10,873 different firms during the period 1964-2005. The dependent variable, EBIT, is earnings before interest and taxes, deflated by market value of equity at the beginning of the period. $R$ is the stock rate of return of the firm, measured compounding twelve monthly CRSP stock returns ending three months after fiscal year end. $D$ is a dummy variable that equals 1 in the case of bad news (negative or zero stock rate of return) and 0 in the case of good news (positive stock rate of return). LEV equals Leverage $\times$ Byld, where Leverage is total interest-bearing debt scaled by total assets, measured at the start of the fiscal year, and Byld is Moody's seasoned Baa corporate bond annual yield (in percentage). TAX $c$ equals the residuals of a regression of TAX on net income. TAX equals the highest statutory corporate income tax rate if the firm has high marginal tax rate and 0 otherwise. TAX $u$ equals 1 if the average over three years $(t$ to $t-2)$ of the ratio current income tax (Compustat \#16-\#50) over tax expense (Compustat \#16) is between 0.8 and 1.2, and 0 otherwise.

The $t$-statistics are based on standard errors clustered at the firm and year level (Petersen, 2008), which are robust to both heteroskedasticity and within-firm serial correlation. All the $p$-values are based on two-tailed tests.

conservatism forces. Table 6 presents the results of this test. The evidence contained in the Table confirms the previously reported evidence: conditional conservatism is positively associated with debt contracting incentives (Panel A, $\beta_{31}=0.048 ; t$-stat $=$ 4.76 ); and tax pressures (Panel B, $\beta_{31}=0.013$; $t$-stat $=4.06$ ). The results contained in Table 6 also confirm that taxation pressures generate incentives for unconditionally conservative accounting (Panel C, $\beta_{31}=-0.072$; $t$-stat $=-2.73$ ) after controlling for the 
potentially confounding effect of earnings components endogenous to conservatism forces, consistent with the previously reported evidence.

\section{(iv) Portfolio Analysis of the Determinants of Conditional Conservatism}

As an alternative test framework, in addition to analysing how each of the factors drives conditional conservatism on an individual basis, we jointly analyse if firms with a larger aggregate exposure to the four determinants present more conditionally conservative accounting. Our objective is to analyse the interaction between the triggering factors and their overall effect over accounting choice. To do so, we assign each firm a score depending on their exposure to each of the four conservatism triggering factors and unconditional conservatism. High (low) exposure to a determinant is assigned a score of $1(0)$ :

(a) Leverage (Lev): Lev is an indicator variable that equals 1 if LEV (see Table 1) is above the median and 0 otherwise.

(b) Tax pressures for conditional conservatism (Taxc): Taxc equals 1 if TAX $c$ (see Table 1 ) is above the median and 0 otherwise.

(c) Tax pressures for unconditional conservatism (TAXu): TAX $u$ equals 1 if the average over three years ( $t$ to $t-2$ ) of the ratio current income tax over tax expense is between 0.8 and 1.2 , and 0 otherwise.

(d) Political pressures for conditional conservatism (REGc): REG $c$ equals 1 in years in which there is a decline in the rate of growth of GDP and an increase in the rate of inflation and 0 otherwise.

(e) Political pressures for unconditional conservatism (REGu): REG $u$ equals 1 if sales deflated by (industry total sales/number of firms in the industry) is in the top quartile and 0 otherwise.

(f) Auditor Litigation risk period (LITA): LITA equals 1 if the firm is audited by a large auditing firm and the fiscal year is in a high auditor litigation period, 0 otherwise.

(g) Firm-level litigation risk (LITF): LITF equals 1 if the Firm litigation risk proxy is in the top quartile of the annual distribution and 0 otherwise.

(h) Unconditional conservatism (UC): UC equals 1 if UCons (see Table 1) is above the median, and 0 otherwise.

Based on these scores, we create portfolios of firm-year observations. For example, in portfolio 1 we classify firm-year observations with a score of 1 on Lev, 0 on Taxc, 0 on TAX $u, 0$ on REG $c, 0$ on REG $u, 0$ on LITA, 0 on LITF, and 0 on UC; in portfolio 2 we classify firm-year observations with a score of 1 on $L e v, 1$ on Taxc, 0 on TAX $u, 0$ on REG $c$, 0 on REG $u, 0$ on LITA, 0 on LITF, and 0 on UC; and so on. The combination of the eight variables (the four determinants, including three definitions of the determinants that capture incentives for unconditional conservatism, plus one control for cumulative unconditional conservatism) originates 256 portfolios $\left(2^{8}\right)$. Next, we estimate the Basu model (1) for each of these portfolios to obtain $\beta_{3}$, the asymmetric timeliness coefficient. To improve the robustness of our findings, we remove 9 portfolios that 
produce a negative $\beta_{3}$ estimate. This yields a final set of 247 usable portfolios. We use the estimated $\beta_{3}$ coefficients (conditional conservatism measures) from these regressions as the dependent variable in a weighted regression of this coefficient on the four economic determinants of conditional conservatism and control variables for unconditional conservatism. Inspired by Cremers and Nair (2005), to increase the power of our tests, we take into account the precision in the estimation of the $\beta_{3}$ coefficients. We use the inverse of the square of the standard error of the estimated $\beta_{3}$ coefficient to weight the variables in the regression below.

$$
\begin{aligned}
\text { CCons }= & \gamma_{0}+\gamma_{1} \text { Lev }+\gamma_{2} \mathrm{LITA}+\gamma_{3} \mathrm{LITF}+\gamma_{4} \text { Tax } c+\gamma_{5} \text { TAX } u+\gamma_{6} \mathrm{REG} c \\
& +\gamma_{7} \mathrm{REG} u+\gamma_{8} \mathrm{UC}+\varepsilon
\end{aligned}
$$

where CCons is the $\beta_{3}$ coefficient estimated for each portfolio. The explanatory variables have already been defined above.

Results of the portfolio approach are reported in Table 7 and are consistent with the main results reported in Tables 2 and 3. Table 7 Panel A contains descriptive statistics of our measure of conditional conservatism at the portfolio level (CCons). The mean (median) value of CCons, the $\beta_{3}$ coefficient of the Basu regression (1), is 0.359 (0.288) consistent with a robust presence of conditional conservatism in all portfolios. The mean (median) number of observations per portfolio equals 372 (252). Table 7 Panel B presents Pearson correlation coefficients of the determinants and CCons. Analysing the correlations between our proxies of the determinants, it can be readily observed that the proxies that measure incentives for conditional conservatism (Lev, LITA, Taxc and $\operatorname{REG} c$ ) are all positively associated to CCons. The proxies that measure incentives for unconditional conservatism (LITF, TAX $u$ and REG $u$ ) also behave as expected, and are all negatively associated with CCons, as is UC, our proxy for unconditional conservatism.

Table 7 Panel C presents results of running equation (4) above. The results confirm that all the conservatism triggering factors drive conditional conservatism in the expected direction $(\operatorname{Lev}=0.140, t$-stat $=8.73 ; \mathrm{LITA}=0.070, t$-stat $=4.93$; $\operatorname{Taxc}=0.091$, $t$-stat $=6.52$; and REG $c=0.021, t$-stat $=1.91$, respectively). Additionally, the results confirm that our proxies for economic determinants of unconditional conservatism are negatively associated with conditional conservatism $(\mathrm{LITF}=-0.045, t$-stat $=-3.45$; $\mathrm{TAX} u=-0.052, t$-stat $=-4.06$; and REG $u=-0.113, t$-stat $=-8.18$, respectively) . These negative relations are consistent with our findings in previous analyses and confirm that time-invariant exposure to litigation, regulation and taxation pressures likely induces more unconditionally conservative accounting choices, which reduces the opportunities to be conditionally conservative. Put together, this evidence is consistent with these three triggering factors generating incentives both for conditional and unconditional conservatism and with the increases in unconditional conservatism not exhausting the opportunities (and incentives) for conditional conservatism. Similarly, our proxy for the level of unconditional conservatism is also negative and significant $(\mathrm{UC}=-0.058, t$-stat $=-3.96)$, consistent with the arguments in Beaver and Ryan (2005) that unconditional conservatism pre-empts conditional conservatism. From the evidence presented in this table, it can be readily observed that although some of our variable definitions may appear to over-simplify the underlying concepts, they explain a significant amount of the variation in conditional conservatism (the adjusted $R^{2}$ equals $0.638)$. 
Table 7

Robustness Tests

Portfolio Analysis of Conditional Conservatism Determinants

\begin{tabular}{|c|c|c|c|c|c|c|c|}
\hline \multicolumn{8}{|c|}{ Panel A: Portfolio Summary Statistics } \\
\hline Variable & Mean & Std. Dev. & $P 10$ & $P 25$ & $P 50$ & P75 & $P 90$ \\
\hline CCons $\left(\beta_{3}\right)$ & 0.359 & 0.315 & 0.063 & 0.151 & 0.288 & 0.458 & 0.716 \\
\hline Portfolio no. of obs & 372 & 382 & 81 & 146 & 252 & 430 & 840 \\
\hline \multicolumn{8}{|c|}{ Panel B: Pearson Correlations } \\
\hline$L e v$ & LITA & LITF & Taxc & TAXu & $R E G c$ & $R E G u$ & $U C$ \\
\hline CCons $\left(\beta_{3}\right)$ & 0.313 & -0.190 & 0.322 & -0.115 & 0.088 & -0.086 & -0.273 \\
\hline \multicolumn{8}{|c|}{ Panel C: Portfolio Regressions; Dependent Variable $C$ Cons $\left(\beta_{3}\right)$} \\
\hline & \multicolumn{2}{|c|}{ Exp. Sign } & Coef. & \multicolumn{2}{|l|}{$t$-stat } & \multicolumn{2}{|c|}{ p-value } \\
\hline Lev & \multicolumn{2}{|l|}{+} & 0.140 & \multicolumn{2}{|c|}{8.73} & \multicolumn{2}{|c|}{0.00} \\
\hline LITA & \multicolumn{2}{|l|}{+} & 0.070 & \multicolumn{2}{|c|}{4.93} & \multicolumn{2}{|c|}{0.00} \\
\hline LITF & \multirow{2}{*}{\multicolumn{2}{|c|}{-}} & -0.045 & \multicolumn{2}{|c|}{-3.45} & \multicolumn{2}{|c|}{0.00} \\
\hline Taxc & & & 0.091 & \multirow{2}{*}{\multicolumn{2}{|c|}{$\begin{array}{r}6.52 \\
-4.06\end{array}$}} & \multicolumn{2}{|c|}{0.00} \\
\hline ТАХ $u$ & \multicolumn{2}{|l|}{-} & -0.052 & & & \multicolumn{2}{|c|}{0.00} \\
\hline REG $c$ & \multicolumn{2}{|l|}{+} & 0.021 & \multicolumn{2}{|c|}{1.91} & \multicolumn{2}{|c|}{0.06} \\
\hline REG $u$ & \multirow{2}{*}{\multicolumn{2}{|c|}{-}} & -0.113 & \multicolumn{2}{|c|}{-8.18} & \multicolumn{2}{|c|}{0.00} \\
\hline UC & & & -0.058 & & & & 00 \\
\hline Intercept & \multicolumn{2}{|l|}{$?$} & 0.229 & \multicolumn{2}{|c|}{14.3} & \multicolumn{2}{|c|}{0.00} \\
\hline \multirow{2}{*}{\multicolumn{3}{|c|}{$\begin{array}{l}\text { N. of obs. } \\
\text { Adj. } R \text {-squared }\end{array}$}} & 247 & & & & \\
\hline & & & 0.638 & & & & \\
\hline
\end{tabular}

Notes:

The dependent variable CCons, the level of conditional conservatism, is the $\beta_{3}$ coefficient estimated by running the Basu model for each of 256 portfolios created on the basis of assigning each firm a score on the four determinants of conditional conservatism and on the controls for unconditional conservatism, as described in the next paragraph. Lev is an indicator variable that equals 1 if LEV (see Table 1) is above the median and 0 otherwise. LITA is an indicator variable that equals 1 if the company's auditor is a big auditing firm (Compustat item \#149 between 1 and 8) and if the fiscal year is in a high auditor litigation period, and 0 otherwise. Taxc equals 1 if TAX $c$ (see Table 1) is above the median and 0 otherwise. TAX $u$ equals 1 if the average over three years $(t$ to $t-2)$ of the ratio current income tax (Compustat \#16-\#50) over tax expense (Compustat \#16) is between 0.8 and 1.2, and 0 otherwise. REG $c$ is an indicator variable taking the value of 1 in years in which there is a decline in the rate of growth of the GDP and an increase in the rate of inflation, and 0 otherwise. REG $u$ is an indicator variable that equals 1 if sales deflated by (industry total sales/number of firms in the industry) is in the top quartile and 0 otherwise. UC is an indicator variable for the level of unconditional conservatism that equals 1 if UCons (see Table 1) is above the median and 0 otherwise. The bias component is a measure of unconditional conservatism estimated as described in the text. The regressions report $t$-statistics based on Huber-White robust standard errors and the $p$-values are based on two-tailed tests. Bold figures in Panel B indicate statistical significance at the $1 \%$ level.

Based on the scores of each determinant of conservatism, we create portfolios of firm-year observations and run the Basu model $X_{i t}=\beta_{0}+\beta_{1} D_{i t}+\beta_{2} R_{i t}+\beta_{3} D_{i t} R_{i t}+\mu_{i t}$, to obtain an estimate of $\beta_{3}$ for each portfolio. For example, we classify in portfolio 1 firm-year observations with a score of 1 on Lev, 0 on LITA, 0 on LITF, 0 on Taxc, 0 on TAX $u, 0$ on REG $c, 0$ on REG $u$, and 0 on UC; in portfolio 2 we classify firm-year observations with a score of 1 on Lev, 1 on LITA, 0 on LITF, 0 on Taxc, 0 on TAX $u, 0$ on REG $c, 0$ on REG $u$, and $0 \mathrm{on} \mathrm{UC;} \mathrm{and} \mathrm{so} \mathrm{on.} \mathrm{Following} \mathrm{this} \mathrm{procedure,} \mathrm{we} \mathrm{create} 256\left(2^{8}\right)$ portfolios. To improve the robustness of CCons, we remove 9 portfolios that produce a negative $\beta_{3}$; this results in 247 valid portfolios. Panel A contains the descriptive statistics of these portfolios. 
(v) Alternative Proxy of Conditional Conservatism: The Asymmetric Persistence Model

The asymmetric recognition criteria for economic gains and losses in earnings implies that gains are recognized as persistent components of earnings, while economic losses are recognized fully in the period when they become known, and thus behave as temporary income decreases that reverse in the following period. Therefore, a consequence of conditional conservatism is the asymmetric persistence of earnings (Basu, 1997; Pope and Walker, 1999; and Ball and Shivakumar, 2005). As a robustness check of the association between conditional conservatism and the four economic determinants, we study the association between each of the determinants and the asymmetric persistence of earnings. To do so, we use the time series model of asymmetric persistence of income changes developed by Basu (1997) and Ball and Shivakumar (2005), incorporating the determinants as we did previously (see model 2):

$$
\begin{aligned}
\Delta \mathrm{NI}_{t}= & \beta_{0}+\beta_{01} \mathrm{DET}_{t}+\beta_{1} D \Delta \mathrm{NI}_{t-1}+\beta_{11} D \Delta \mathrm{NI}_{t-1} \mathrm{DET}_{t}+\beta_{2} \Delta \mathrm{NI}_{t-1} \\
& +\beta_{21} \Delta \mathrm{NI}_{t-1} \mathrm{DET}_{t}+\beta_{3} \Delta \mathrm{NI}_{t-1} D \Delta \mathrm{NI}_{t-1}+\beta_{31} \Delta \mathrm{NI}_{t-1} D \Delta \mathrm{NI}_{t-1} \mathrm{DET}_{t}+\mu_{t}
\end{aligned}
$$

where $\Delta \mathrm{NI}_{t}$ is change in net income deflated by beginning-of-period total assets, and $D \Delta \mathrm{NI}_{t-1}$ is a dummy variable taking the value of one if the prior year change in net income is negative; and 0 otherwise. The economic determinants (DET) are measured as before. In model (5), the coefficient $\beta_{3}$ captures conditional conservatism (asymmetric persistence). Given that negative earnings changes reverse, $\beta_{3}$ is expected to be significantly negative if losses are reflected on a timelier basis than gains. Good news in earnings being persistent implies $\beta_{2}$ should be close to zero or positive. We expect that asymmetric persistence will increase whenever debt-contracting, litigation, taxation and regulation pressures increase. These effects will be captured by the $\beta_{31}$ coefficient in model (5).

Table 8 Panels A to D presents results of running equation (5) above for each of the four economic determinants. The results confirm that conditional conservatism as reflected by the asymmetric persistence of earnings appears as a reaction to changes in the level of contracting incentives (Panel A, $\beta_{31}=-0.017 ; t$-stat $\left.=-2.21\right)$; taxation pressures (Panel C, $\beta_{31}=-0.002 ; t$-stat $\left.=-2.75\right)$; and regulation incentives (Panel D, $\beta_{31}=-0.097 ; t$-stat $\left.=-2.03\right)$. Using this alternative measure of conditional conservatism, our proxy for litigation-related incentives becomes insignificant (Panel B, $\beta_{31}=0.055 ; t$-stat $=1.33$ ). This is likely caused by noise in the asymmetric persistence measure, which is less precise than the one proposed by Basu. It should be noted, however, that asymmetric persistence measures avoid the recent criticism in Dietrich et al. (2007), who suggest that the Basu model might be biased. However, and as noted by Ryan (2006) and Ball and Kothari (2007), the biases in the Basu market based model are likely to be small. Put together, the evidence from both the asymmetric timeliness and asymmetric persistence tests strongly supports our prediction that regulation and taxation pressures induce conditional conservatism.

\section{SUMMARYAND CONCLUSIONS}

Using a large sample of US firms for the period 1964 to 2005, we analyse how contracting, litigation, taxation and regulation affect the choice of conditional versus 
Table 8

Robustness Tests

Asymmetric Persistence Model: Effect of Individual Determinants on Conditional Conservatism

$$
\begin{aligned}
& \Delta \mathrm{NI}_{t}=\beta_{0}+\beta_{1} D \Delta \mathrm{NI}_{t-1}+\beta_{01} \mathrm{DET}_{t}+\beta_{11} D \Delta \mathrm{NI}_{t-1} \mathrm{DET}_{t}+\beta_{2} \Delta \mathrm{NI}_{t-1} \\
& +\beta_{21} \Delta \mathrm{NI}_{t-1} \mathrm{DET}_{t}+\beta_{3} D \Delta \mathrm{NI}_{t-1} \Delta \mathrm{NI}_{t-1}+\beta_{31} D \Delta \mathrm{NI}_{t-1} \Delta \mathrm{NI}_{t-1} \mathrm{DET}_{t}+\mu_{t}
\end{aligned}
$$

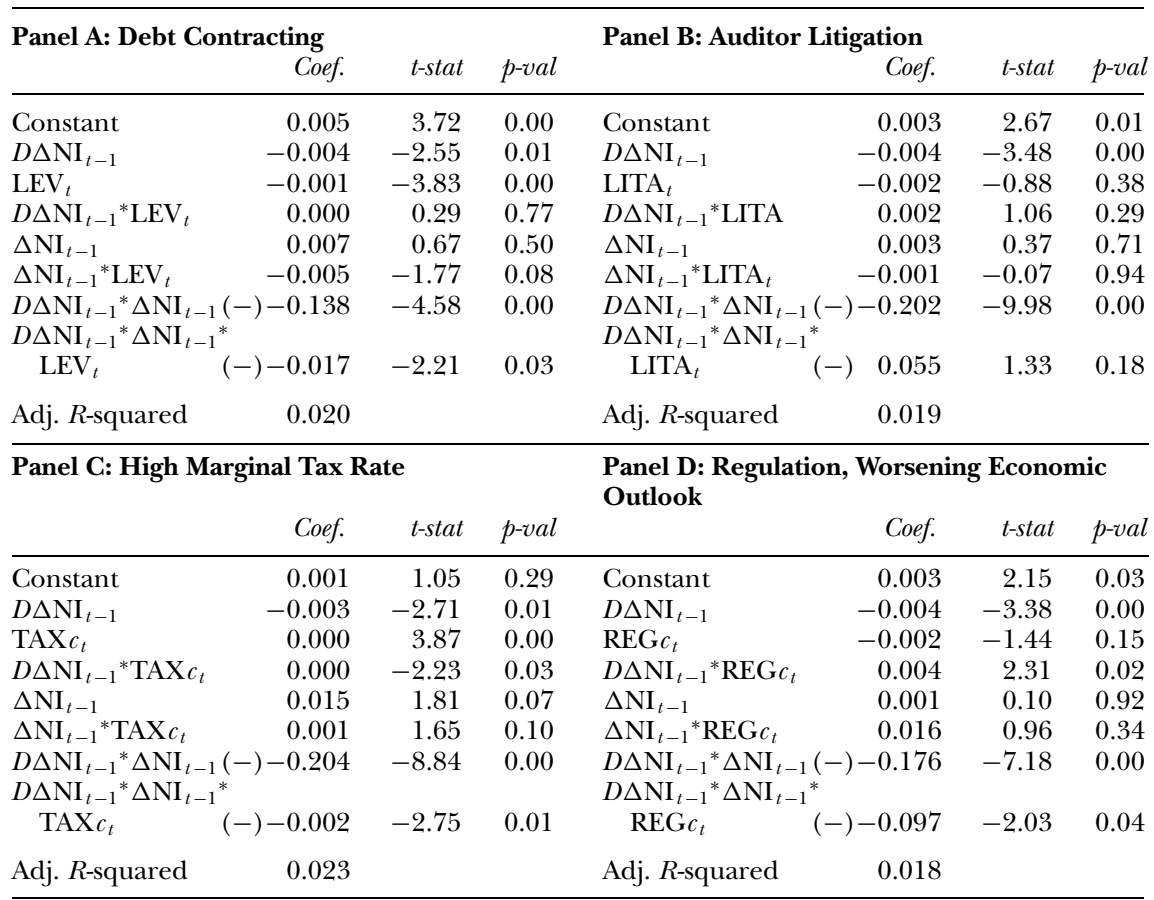

Notes:

The sample contains 88,887 firm-year observations corresponding to 10,511 different firms during the period 1964-2005. The dependent variable, $\Delta \mathrm{NI}_{t}$, is the change in net income, deflated by beginningof-period total assets. $D \Delta \mathrm{NI}_{t-1}$ is a dummy variable that equals 1 if $\Delta \mathrm{NI}_{t-1}<0$, and 0 otherwise. LEV equals Leverage $\times$ Byld, where Leverage is total interest-bearing debt scaled by total assets, measured at the start of the fiscal year, and Byld is Moody's seasoned Baa corporate bond annual yield (in percentage). LITA is an indicator variable that equals 1 if the company's auditor is a big auditing firm (Compustat item \#149 between 1 and 8 ) and if the fiscal year is in a high auditor litigation period, and 0 otherwise. High auditor litigation periods are 1967 to 1975,1983 to 1995 , and 2001 to 2005. TAX $c$ equals the residuals of a regression of TAX on net income. TAX equals the highest statutory corporate income tax rate if the firm has high marginal tax rate and 0 otherwise. REG $c$ is an indicator variable taking the value of 1 if the firm pertains to a regulated industry (financials and utilities) in years in which there is a decline in the rate of growth of the GDP and an increase in the rate of inflation, and 0 otherwise. To reduce the effect of outliers, the sample only includes observations in the range $-0.2 \leq \Delta \mathrm{NI}_{t} \leq 0.2$, which is equivalent to removing the top and bottom 2.5 percentiles.

The $t$-statistics are based on standard errors clustered at the firm and year level (Petersen, 2008), which are robust to both heteroskedasticity and within-firm serial correlation. All the $p$-values are based on two-tailed tests. 
unconditional conservative accounting policies. There is scarce empirical evidence and mixed views on which are the economic determinants of conservatism in accounting and what types of conservatism they trigger. Prior work by Watts (2003), Ball (2001), Ball and Shivakumar (2005) and Basu (2005) identifies four main triggering factors for conservatism: contracting, litigation, taxation and regulation. We study if these factors induce conditional conservatism or if some of them create incentives only for unconditional conservatism, as suggested by prior empirical work (Qiang, 2007).

Our empirical results are consistent with contracting inducing conditional conservatism only and with litigation, taxation and regulation inducing both conditional and unconditional conservatism. Contrary to prior research, we show that time-varying taxation and regulation pressures create incentives for shifting income to periods with lower taxation and regulatory pressures. These income shifting strategies induce conditional conservatism, as managers (1) recognize current economic losses that otherwise they would have chosen to delay given their incentives to report aggressively, and (2) delay the recognition of current economic gains that they would have reported otherwise. We construct proxies for taxation and regulation that are able to capture these incentives for the implementation of conditionally conservative accounting policies. Finally, we demonstrate that each of the determinants is associated with incrementally significant effects on conditional conservatism, rejecting the alternative view that some of them may merely capture the same underlying phenomenon.

\section{REFERENCES}

Ahmed, A.S. and S. Duellman (2007), 'Evidence on the Role of Accounting Conservatism in Corporate Governance', Journal of Accounting and Economics, Vol. 43, Nos. 2-3, pp. 411-37.

- B.K. Billings, R.M. Morton and M. Stanford-Harris (2002), 'The Role of Accounting Conservatism in Mitigating Bondholder-Shareholder Conflicts Over Dividend Policy and in Reducing Debt Costs', The Accounting Review, Vol. 77, No. 4, pp. 867-90.

Badertscher, B., J. Phillips, M. Pincus and S. Rego (2006), 'Do Firms Manage Earnings Downward in a Book-Tax Conforming Manner?', Working Paper (University of Iowa).

Ball, R. (2001), 'Infrastructure Requirements for an Economically Efficient System of Public Financial Reporting and Disclosure', Brookings-Wharton Papers on Financial Services, pp. $127-82$.

and S.P. Kothari (2007), 'Econometrics of the Basu Asymmetric Timeliness Coefficient and Accounting Conservatism', Working Paper (University of Chicago).

— and L. Shivakumar (2005), 'Earnings Quality in UK Private Firms: Comparative Loss Recognition Timeliness', Journal of Accounting and Economics, Vol. 39, No. 1, pp. 83-128.

- S.P. Kothari and A. Robin (2000), 'The Effect of International Institutional Factors on Properties of Accounting Earnings', Journal of Accounting and Economics, Vol. 29, No. 1, pp. 1-51.

, A. Robin and G. Sadka (2008), 'Is Financial Reporting Shaped by Equity Markets or by Debt Markets? An International Study of Timeliness and Conservatism', Review of Accounting Studies, Vol. 13, Nos. 2-3, pp.168-205.

in Four East Asian Countries', Journal of Accounting and Economics, Vol. 36, Nos. 1-3, pp. 235-70.

Basu, S. (1997), 'The Conservatism Principle and the Asymmetric Timeliness of Earnings', Journal of Accounting and Economics, Vol. 24, No. 1, pp. 3-37.

(2001), 'Discussion of "On the Asymmetric Recognition of Good and Bad News in France, Germany and the United Kingdom"', Journal of Business Finance E् Accounting, Vol. 28, Nos. 9-10, pp. 1333-49. 
Basu, S. (2005), 'Discussion of "Conditional and Unconditional Conservatism: Concepts and Modeling”, Review of Accounting Studies, Vol. 10, Nos. 2-3, pp. 311-21.

, L.-S. Hwang and C.-L. Jan (2001), 'Auditor Conservatism and Quarterly Earnings', Working Paper (City University of Hong Kong).

Beatty, A., J. Weber and J.J. Yu (2008), 'Conservatism and Debt', Journal of Accounting and Economics, Vol. 45, Nos. 2-3, pp. 154-74.

Beaver, W.H. and S.G. Ryan (2000), 'Biases and Lags in Book Value and their Effects on the Ability of the Book-to-Market Ratio to Predict Book Return on Equity', Journal of Accounting Research, Vol. 38, No. 1, pp. 127-48.

$-12005)$, 'Conditional and Unconditional Conservatism: Concepts and Modeling', Review of Accounting Studies, Vol. 10, Nos. 2-3, pp. 269-309.

Beekes, W., P. Pope and S. Young (2004), 'The Link between Earnings Timeliness, Earnings Conservatism and Board Composition: Evidence from the UK', Corporate Governance, Vol. 12, No. 1, pp. 47-59.

Bushman, R.M. and J.D. Piotroski (2006), 'Financial Reporting Incentives for Conservative Accounting: The Influence of Legal and Political Institutions', Journal of Accounting and Economics, Vol. 42, Nos. 1-2, pp. 107-48.

Cahan, S. F. (1992), 'The Effect of Antitrust Investigations on Discretionary Accruals: A Refined Test of The Political-Cost Hypotheses', The Accounting Review, Vol. 67, No. 1, pp. 77-95.

Callen, J.L., O.K. Hope and D. Segal (2008), 'The Pricing of Conservative Accounting and the Measurement of Conservatism at the Firm-Year Level', Review of Accounting Studies (forthcoming).

Chung, H.H. and J.P. Wynn (2008), 'Managerial Legal Liability Coverage and Earnings Conservatism', Journal of Accounting and Economics, Vol. 46, No. 1, pp.135-53.

Cremers, K. J. M. and V.B. Nair (2005), 'Governance Mechanisms and Equity Prices', Journal of Finance, Vol. 60, No. 6, pp. 2859-94.

Davila, A. and F. Penalva. (2006), 'Governance Structure and the Weighting of Performance Measures in CEO Compensation', Review of Accounting Studies, Vol. 11, No. 4, pp. 463-93.

Desai, M. A. and D. Dharmapala (2006), 'Corporate Tax Avoidance and High-Powered Incentives', Journal of Financial Economics. Vol. 79, No. 1, pp. 145-79.

Dietrich, J.R., K.A. Muller and E.J. Riedl (2007), 'Asymmetric Timeliness Tests of Accounting Conservatism', Review of Accounting Studies, Vol. 12, No. 1, pp. 95-124.

Dyreng, S.D., M. Hanlon and E.L. Maydew (2008), 'Long-Run Corporate Tax Avoidance', The Accounting Review, Vol. 83, No. 1, pp. 61-82.

Fama, E. and J. MacBeth (1973), 'Risk, Return, and Equilibrium: Empirical Tests', Journal of Political Economy, Vol. 81, No. 3, pp. 607-36.

García Lara, J.M., B. García Osma and A. Mora (2005), 'The Effect of Earnings Management on the Asymmetric Timeliness of Earnings', Journal of Business Finance E Accounting, Vol. 34, Nos. 3-4, pp. 691-726.

- and F. Penalva (2007), 'Board of Directors' Characteristics and Conditional Accounting Conservatism: Spanish Evidence', European Accounting Review, Vol. 16, No. 4, pp. 727-55. of Accounting Studies (forthcoming).

Gassen, J., R.U. Fülbier and T. Sellhorn (2006), 'International Differences in Conditional Conservatism: The Role of Unconditional Conservatism and Income Smoothing', European Accounting Review, Vol. 15, No. 4, pp. 527-64.

Giner, B. and W. Rees (2001), 'On the Asymmetric Recognition of Good and Bad News in France, Germany and the United Kingdom', Journal of Business Finance E Accounting, Vol. 28, Nos. 9-10, pp. 1285-331.

Givoly, D. and C. Hayn (2000), 'The Changing Time-Series Properties of Earnings, Cash Flows and Accruals: Has Financial Reporting Become More Conservative?', Journal of Accounting and Economics, Vol. 29, No. 3, pp. 287-320.

and A. Natarajan (2007), 'Measuring Reporting Conservatism', The Accounting Review, Vol. 82, No. 1, pp. 65-106.

Graham, J.R. (1996), 'Proxies for the Marginal Tax Rate', Journal of Financial Economics, Vol. 42, No. 2, pp. 187-221. 
Graham, J.R. and L.F. Mills (2008), 'Using Tax Return Data to Simulate Corporate Marginal Tax Rates', Journal of Accounting and Economics (forthcoming).

Guay, W. and R. Verrecchia (2006), 'Discussion of an Economic Framework for Conservative Accounting and Bushman and Piotroski (2006)', Journal of Accounting and Economics, Vol. 42, Nos. 1-2, pp. 149-65.

Guenther, D.A. (1994), 'Earnings Management in Response to Corporate Tax Rate Changes: Evidence from the 1986 Tax Reform Act', The Accounting Review, Vol. 69, No. 1, pp. 230-43.

Han, J. and S. Wang (1998), 'Political Costs and Earnings Management of Oil Companies During the 1990 Persian Gulf Crisis', The Accounting Review, Vol. 73, No. 1, pp. 103-17.

Hausman, J.A. and D.A. Wise (1977), 'Social Experimentation, Truncated Distributions, and Efficient Estimation', Econometrica, Vol. 45, No. 4, pp. 919-38.

Healy, P.M. (1985), 'The Effect of Bonus Schemes on Accounting Decisions', Journal of Accounting and Economics, Vol. 7, Nos. 1-3, pp. 85-107.

Heninger, W.G. (2001), 'The Association Between Auditor Litigation and Abnormal Accruals', The Accounting Review, Vol. 76, No. 1, pp. 111-25.

Holthausen, R.W. and R.L. Watts (2001), 'The Relevance of the Value Relevance Literature for Financial Accounting Standard Setting', Journal of Accounting E E Economics, Vol. 31, Nos. 1-3, pp. 3-75.

Hribar, P. and D.W. Collins (2002), 'Errors in Estimating Accruals: Implications for Empirical Research', Journal of Accounting Research, Vol. 40, No. 1, pp. 105-34.

Huijgen, C. and M. Lubberink (2005), 'Earnings Conservatism, Litigation, and Contracting: The Case of Cross-Listed Firms', Journal of Business Finance $\mathcal{E}$ Accounting, Vol. 32, Nos. 7-8, pp. 1275-309.

Internal Revenue Service, Publication 535 (2007), Business Expenses.

— , Publication 538 (2008), Accounting Periods and Methods.

Johnson, M., R. Kasznik and K. Nelson (2001), 'The Impact of Securities Litigation Reform on the Disclosure of Forward-Looking Information by High Technology Firms', Journal of Accounting Research, Vol. 39, pp. 297-327.

Jones, J. (1991), 'Earnings Management During Import Relief Investigations', Journal of Accounting Research, Vol. 29, No. 2, pp. 193-228.

Kellogg, R. L. (1984), 'Accounting Activities, Security Prices, and Class Action Lawsuits', Journal of Accounting and Economics, Vol. 6, No. 3, pp. 185-204.

Key, K. G. (1997), 'Political Cost Incentives for Earnings Management in the Cable Television Industry', Journal of Accounting and Economics, Vol. 23, No. 3, pp. 309-37.

Khurana, I. K. and K. K. Raman (2004), 'Litigation Risk and the Financial Reporting Credibility of Big 4 Versus Non-Big 4 Audits: Evidence from Anglo-American Countries', The Accounting Review, Vol. 79, pp. 473-95.

La Porta, R., F. Lopez-de-Silanes and A. Shleifer (1998), 'Law and Finance', Journal of Political Economy, Vol. 106, No. 6, pp. 1113-55. Vol. 54, No. 2, pp. 471-517.

LaFond, R. and R.L. Watts (2008), 'The Information Role of Conservative Financial Statements', The Accounting Review, Vol. 83, No. 2, pp. 443-78.

Leftwich, R. (1983), 'Accounting Information in Private Markets: Evidence from Private Lending Agreements', The Accounting Review, Vol. 58, No. 1, pp. 23-42.

Navissi, F. (1999), 'Earnings Management Under Price Regulation', Contemporary Accounting Research, Vol. 16, pp. 281-304.

Newey, W.K. and K.D. West (1987), 'A Simple, Positive Semi-Definite, Heteroskedasticity and Autocorrelation Consistent Covariance Matrix', Econometrica, Vol. 55, pp. 703-8.

Northcut, D. and C. Vines (1998), 'Effective Tax Rates and Political Costs', Journal of the American Taxation Association, Vol. 20, No. 2, pp. 22-36.

Penman, S. and X. Zhang (2002), 'Accounting Conservatism, the Quality of Earnings, and Stock Returns', The Accounting Review, Vol. 77, No. 2, pp. 237-64.

Petersen, M.A. (2008), 'Estimating Standard Errors in Finance Panel Data Sets: Comparing Approaches', Review of Financial Studies (forthcoming).

Plesko, G.A. (2003), 'An Evaluation of Alternative Measures of Corporate Tax Rates', Journal of Accounting and Economics, Vol. 35, No. 2, pp. 201-26. 
Pope, P.F. and M. Walker (1999), 'International Differences in the Timeliness, Conservatism and Classification of Earnings', Journal of Accounting Research, Vol. 37 (Supplement), pp. 53-99.

(2003), 'Ex-ante and Ex-post Accounting Conservatism, Asset Recognition and Asymmetric Earnings Timeliness', Working Paper (Lancaster University).

Qiang, X. (2007), 'The Effects of Contracting, Litigation, Regulation, and Tax Costs on Conditional and Unconditional Conservatism: Cross-Sectional Evidence at the Firm Level', The Accounting Review, Vol. 82, No. 3, pp. 759-97.

Raonic, I., S.J. Mcleay and I. Asimakopoulos (2004), 'The Timeliness of Income Recognition by European Companies: an Analysis of Institutional and Market Complexity', Journal of Business Finance Eै Accounting, Vol. 31, Nos. 1-2, pp. 115-48.

Rego, S.O. (2003), 'Tax-Avoidance Activities of US Multinational Corporations', Contemporary Accounting Research, Vol. 20, pp. 805-33.

Roychowdhury, S. and R. Watts (2007), 'Asymmetric Timeliness of Earnings, Market to Book and Conservatism in Financial Reporting', Journal of Accounting and Economics, Vol. 44, Nos. 1-2, pp. 2-31.

Ryan, S.G. (2006), 'Identifying Conditional Conservatism', European Accounting Review, Vol. 15, No. 4, pp. 511-25.

and P. A. Zarowin (2003), 'Why has the Contemporaneous Linear Returns-Earnings Relation Declined?', The Accounting Review, Vol. 78, No. 2, pp. 523-53.

Scholes, M.S., G. P. Wilson and M. A. Wolfson (1992), 'Firms' Responses to Anticipated Reductions in Tax Rates: The Tax Reform Act of 1986', Journal of Accounting Research, Vol. 30 (Supplement), pp. 161-85.

Seetharaman, A., F. A. Gul and S. G. Lynn (2002), 'Litigation Risk and Audit Fees: Evidence from UK Firms Cross-Listed on US Markets', Journal of Accounting and Economics, Vol. 33, No. 1, pp. 91-115.

Shackelford, D.A. and T. Shevlin (2001), 'Empirical Tax Research in Accounting', Journal of Accounting and Economics, Vol. 31, Nos. 1-3, pp. 321-87.

- J. Slemrod and J.M. Sallee (2007). 'A Unifying Model of How the Tax System and Generally Accepted Accounting Principles Affect Corporate Behavior', Working Paper (University of North Carolina).

Sivakumar, K. and G. Waymire (2003), 'Enforceable Accounting Rules and Income Measurement by Early 20th Century Railroads', Journal of Accounting Research, Vol. 41, No. 2, pp. 397-32.

Stice, J. D. (1991), 'Using Financial and Market Information to Identify Pre-engagement Factors Associated with Lawsuits Against Auditors', The Accounting Review, Vol. 66, No. 3, pp. 516-33.

St. Pierre, K. and J. A. Anderson (1984), 'An Analysis of the Factors Associated with Lawsuits Against Public Accountants', The Accounting Review, Vol. 59, No. 2, pp. 242-63.

Watts, R. (2003), 'Conservatism in Accounting Part I: Explanations and Implications', Accounting Horizons, Vol. 17, No. 3, pp. 207-21.

- and J. Zimmerman (1978), 'Towards a Positive Theory of the Determination of Accounting Standards', The Accounting Review, Vol. 53, No. 1, pp. 112-34.

_ (1986), Positive Accounting Theory (Prentice Hall). 